\title{
Initiator Control of Conjugated Polymer Topology in Ring- Opening Alkyne Metathesis Polymerization
}

\author{
Stephen von Kugelgen ${ }^{\dagger \neq}$, Donatela Bellone ${ }^{\dagger \neq}$, Ryan R. Cloke ${ }^{\dagger}$, Wade Perkins ${ }^{\dagger}$, Felix R. Fischer ${ }^{*} \perp_{s}$ \\ ${ }^{\dagger}$ Department of Chemistry, University of California Berkeley, Berkeley, California 94720, United States \\ ${ }^{\perp}$ Materials Sciences Division, Lawrence Berkeley National Laboratory, Berkeley, California 94720, United States \\ ${ }^{5}$ Kavli Energy Nanosciences Institute at the University of California Berkeley and Lawrence Berkeley National Laboratory, \\ Berkeley, California 94720, United States
}

\begin{tabular}{|c|c|c|}
\hline 1. & Figure S1. Dissociation equilibrium of DME from 2. & S2 \\
\hline 2. & Figure S2. Molecular weight of poly-3a vs. conversion in living ROAMP initiated by 1. & S4 \\
\hline 3. & Figure S3. MALDI mass spectrum of linear poly-3a. & S5 \\
\hline 4. & Table S1. Molecular weight analysis and cyclic polymer selectivity of crude poly-3b. & S6 \\
\hline 5. & Figure S4. GPC traces of crude poly-3b. & S7 \\
\hline 6. & Figure S5. ${ }^{1} \mathrm{H}$ NMR of crude poly-3b. & S8 \\
\hline 7. & Figure S6. Transient ${ }^{1} \mathrm{H}$ NMR spectra of the polymerization of $\mathbf{3}^{*}$ with 1. & S9 \\
\hline 8. & Figure S7. Transient ' H NMR spectra of the polymerization of $\mathbf{3}^{*}$ with $\mathbf{2}$. & S10 \\
\hline 9. & Figure S8. Transient ${ }^{13} \mathrm{C}$ NMR spectra of the polymerization of $\mathbf{3}^{*}$ with $\mathbf{1}$. & S11 \\
\hline 10. & Figure S9. Transient ${ }^{13} \mathrm{C}$ NMR spectra of the polymerization of $3^{*}$ with 2 . & S12 \\
\hline 11. & Figure S10. Pseudo-first order reaction of 4 with $\mathbf{5 a}$. & S13 \\
\hline 12. & Figure S11. Pseudo-first order reaction of $\mathbf{4}$ with $\mathbf{5 b}$. & S14 \\
\hline 13. & Materials and General Methods & S15 \\
\hline 14. & Synthetic Procedures & S16 \\
\hline 15. & Table S2-S6. Crystal data and structure refinement for 2. & $\mathrm{~S} 20$ \\
\hline 16. & Figure S12. 'H NMR (600 MHz, $\left.\mathrm{C}_{6} \mathrm{D}_{6}\right)$ spectrum of 2 ( ${ }^{*}$ solvent residual peak). & S28 \\
\hline 17. & Figure S13. $\left\{{ }^{1} \mathrm{H}\right\}^{13} \mathrm{C}$ NMR $\left(151 \mathrm{MHz}, \mathrm{C}_{6} \mathrm{D}_{6}\right)$ spectrum of 2 ( ${ }^{*}$ solvent residual peak). & S29 \\
\hline 18. & Figure S14. ${ }^{19} \mathrm{~F}$ NMR (376 MHz, $\left.\mathrm{C}_{6} \mathrm{D}_{6}\right)$ spectrum of 2 (* hexafluorobenzene). & S30 \\
\hline 19. & Figure S15. ${ }^{1} \mathrm{H}$ NMR $\left(600 \mathrm{MHz}, \mathrm{CDCl}_{3}\right)$ spectrum of poly-3a. & S31 \\
\hline 20. & Figure S16. $\left\{{ }^{1} \mathrm{H}\right\}^{13} \mathrm{C}$ NMR $\left(126 \mathrm{MHz}, \mathrm{CDCl}_{3}\right)$ spectrum of poly-3a. & S32 \\
\hline 21. & Figure S17. ${ }^{1} \mathrm{H}$ NMR $\left(600 \mathrm{MHz}, \mathrm{CDCl}_{3}\right)$ spectrum of poly-3b. & S33 \\
\hline 22. & Figure S18. $\left\{{ }^{1} \mathrm{H}\right\}^{13} \mathrm{C}$ NMR $\left(126 \mathrm{MHz}, \mathrm{CDCl}_{3}\right)$ spectrum of poly-3b. & S34 \\
\hline 23. & Figure S19. 'H NMR $\left(600 \mathrm{MHz}, \mathrm{CDCl}_{3}\right)$ spectrum of $\mathbf{5 a}$. & S35 \\
\hline 24. & Figure S20. $\left\{{ }^{1} \mathrm{H}\right\}^{13} \mathrm{C}$ NMR $\left(126 \mathrm{MHz}, \mathrm{CDCl}_{3}\right)$ spectrum of $\mathbf{5 a}$. & S36 \\
\hline 25. & References & S37 \\
\hline
\end{tabular}




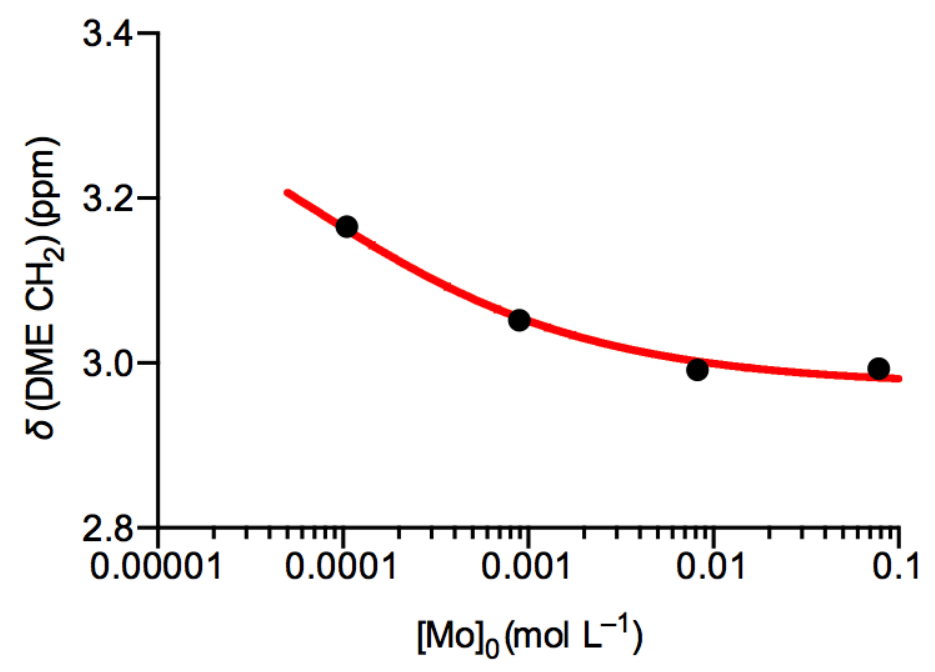

Figure S1. Dissociation equilibrium of DME from 2 determined by ${ }^{1} \mathrm{H}$ NMR dilution experiments.

For the dissociation of DME from $\mathbf{2}$,

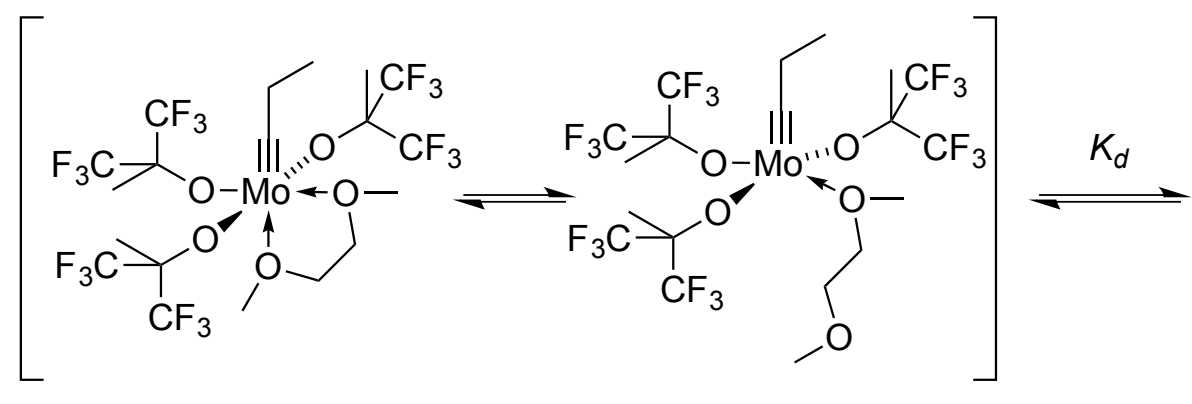

"Mo•DME"

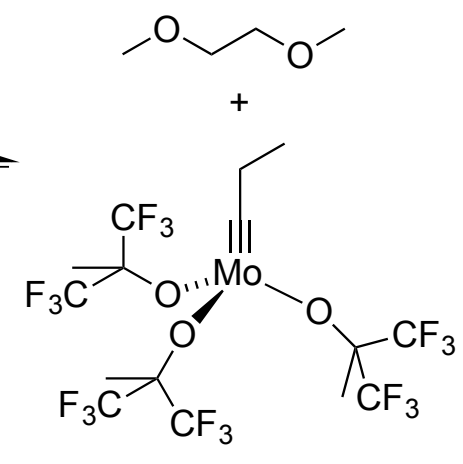

"Mo"

$K_{d}$ is defined:

$$
K_{d}=\frac{[M o][D M E]}{[M o \cdot D M E]}=\frac{[M o]^{2}}{[M o \cdot D M E]}
$$

From mass balance:

$$
[M o]_{0}=[M o \cdot D M E]+[M o]
$$

Solving for $[\mathrm{Mo}]$ and substituting gives:

$$
K_{d}=\frac{\left([M o]_{0}-[M o \cdot D M E]\right)^{2}}{[M o \cdot D M E]}
$$

Multiplication and rearrangement gives a quadratic equation: 


$$
0=[M o \bullet D M E]^{2}-\left(2[M o]_{0}+K_{d}\right)[M o \bullet D M E]+\left([M o]_{0}\right)^{2}
$$

Which can be solved for $[M o \bullet D M E]$ to give:

$$
[M o \cdot D M E]=\frac{2[M o]_{0}+K_{d} \pm \sqrt{\left(2[M o]_{0}+K_{d}\right)^{2}-4\left([M o]_{0}\right)^{2}}}{2}
$$

We take the negative root since $[M o]_{0} \geq[M o \cdot D M E]$ and simplify:

$$
[M o \cdot D M E]=[M o]_{0}+\frac{K_{d}-\sqrt{\left(K_{d}\right)^{2}+4 K_{d}[M o]_{0}}}{2}
$$

The chemical shift observed is simply the weighted average of the chemical shifts of the bound and free species:

$$
\begin{aligned}
\delta_{\text {obs }} & =\frac{\delta_{\text {free }}[M o]+\delta_{\text {bound }}[M o \cdot D M E]}{[M o]_{0}} \\
\delta_{\text {obs }} & =\frac{\delta_{\text {free }}\left([M o]_{0}-[M o \cdot D M E]\right)+\delta_{\text {bound }}[M o \cdot D M E]}{[M o]_{0}} \\
\delta_{\text {obs }} & =\delta_{\text {free }}+\frac{\left(\delta_{\text {bound }}-\delta_{\text {free }}\right)[M o \cdot D M E]}{[M o]_{0}}
\end{aligned}
$$

Letting $\Delta \delta=\delta_{\text {bound }}-\delta_{\text {free }}$ gives a nicer equation:

$$
\delta_{o b s}=\delta_{f r e e}+\Delta \delta \frac{[M o \cdot D M E]}{[M o]_{0}}
$$

Substituting the solution of the quadratic for $[M o \bullet D M E]$ yields our final equation with two parameters that need to be fit to the experimental data in Figure $\mathrm{S} 1$ using a nonlinear regression, the change in chemical shift upon binding, $\Delta \delta$, and $K_{d}$.

$$
\delta_{o b s}=\delta_{\text {free }}+\Delta \delta\left(1+\frac{K_{d}-\sqrt{\left(K_{d}\right)^{2}+4 K_{d}[M o]_{0}}}{2[M o]_{0}}\right)
$$




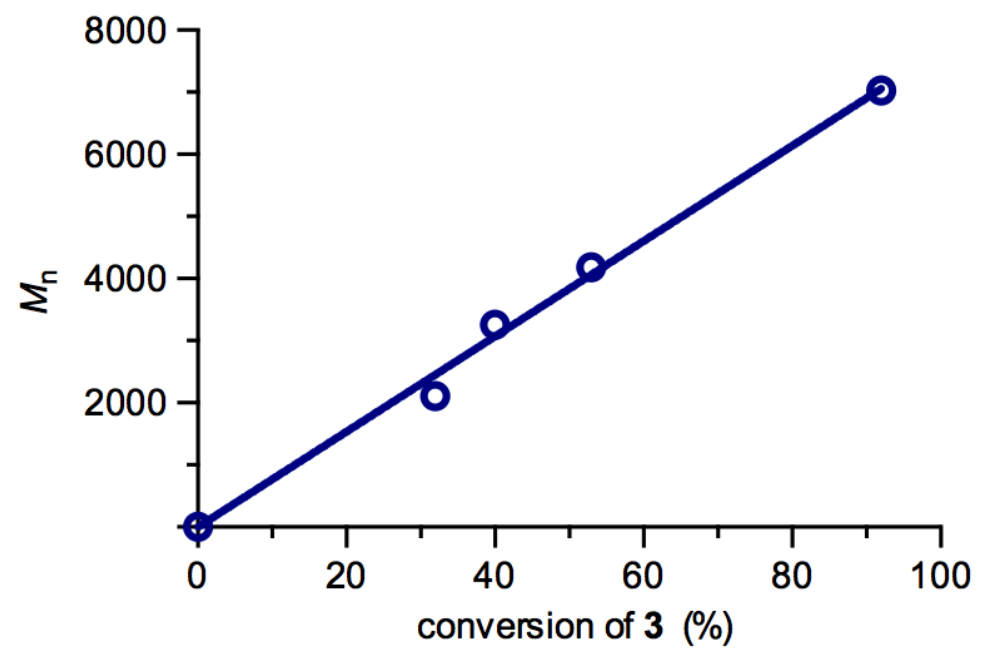

Figure S2. GPC analysis of samples taken at different time points from a polymerization reaction of $\mathbf{3}$ with catalyst 1. $M_{\mathrm{n}}$ increases linearly with the conversion of $\mathbf{3}$. 


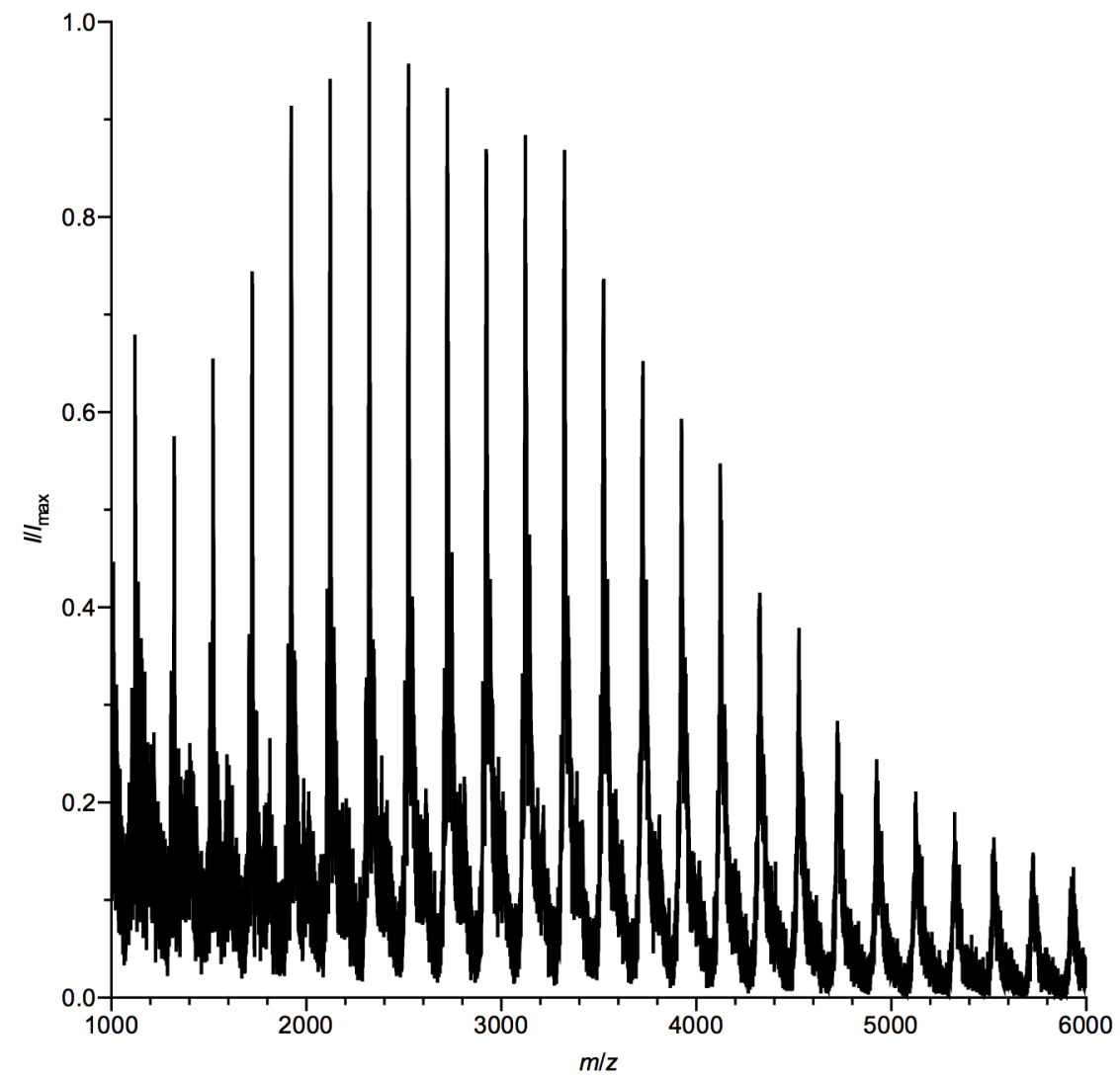

Figure S3. MALDI mass spectrum of linear poly-3a showing peaks separated by integer multiples of the mass of monomer 3 . 
Table S1. Molecular weight analysis and cyclic polymer selectivity of crude poly-3b at [3]/[2] = 5 as a function of concentration.

\begin{tabular}{ccccc}
\hline [2] (mM) & \%cyclic $\mathbf{3 b}^{\mathrm{a}}$ & $M_{\mathrm{n}}{ }^{\mathrm{b}}$ & $M_{\mathrm{w}}{ }^{\mathrm{b}}$ & $\mathrm{PDI}^{\mathrm{b}}$ \\
\hline 10 & 86 & 370 & 840 & 2.2 \\
5 & 91 & 330 & 660 & 2.0 \\
2 & 92 & 280 & 550 & 1.9 \\
1 & 93 & 280 & 530 & 1.8
\end{tabular}

${ }^{\mathrm{a}}$ As determined by ${ }^{1} \mathrm{H}$ NMR integration; ${ }^{\mathrm{b}}$ calibrated to narrow polydispersity polystyrene standards. 


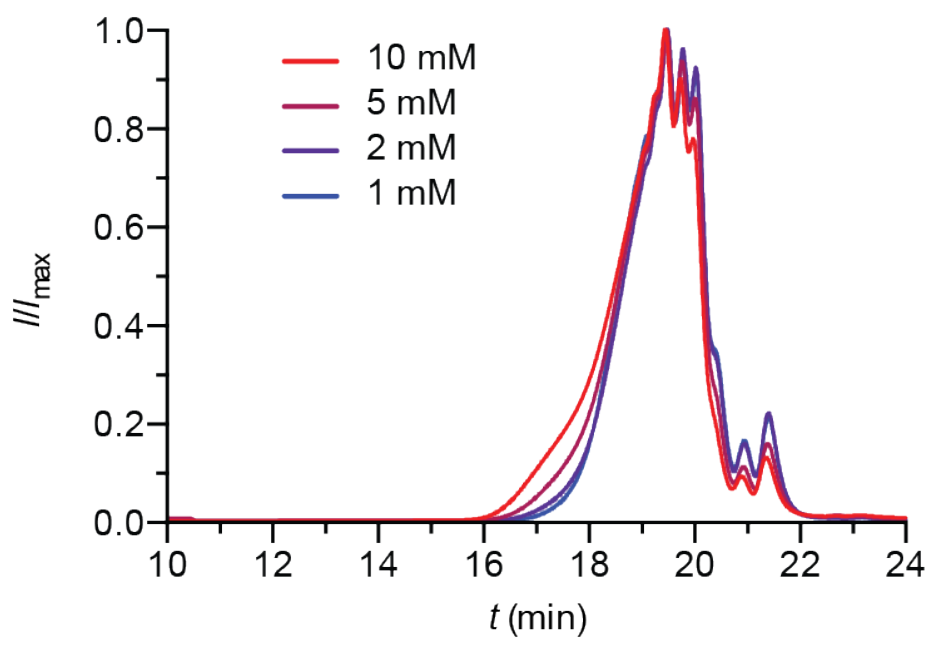

Figure S4. GPC traces for crude poly-3b obtained through ROAMP of 3 with catalyst 2 at [2] = 10, 5, 2, and $1 \mathrm{mM}$ calibrated to linear polystyrene standards. 


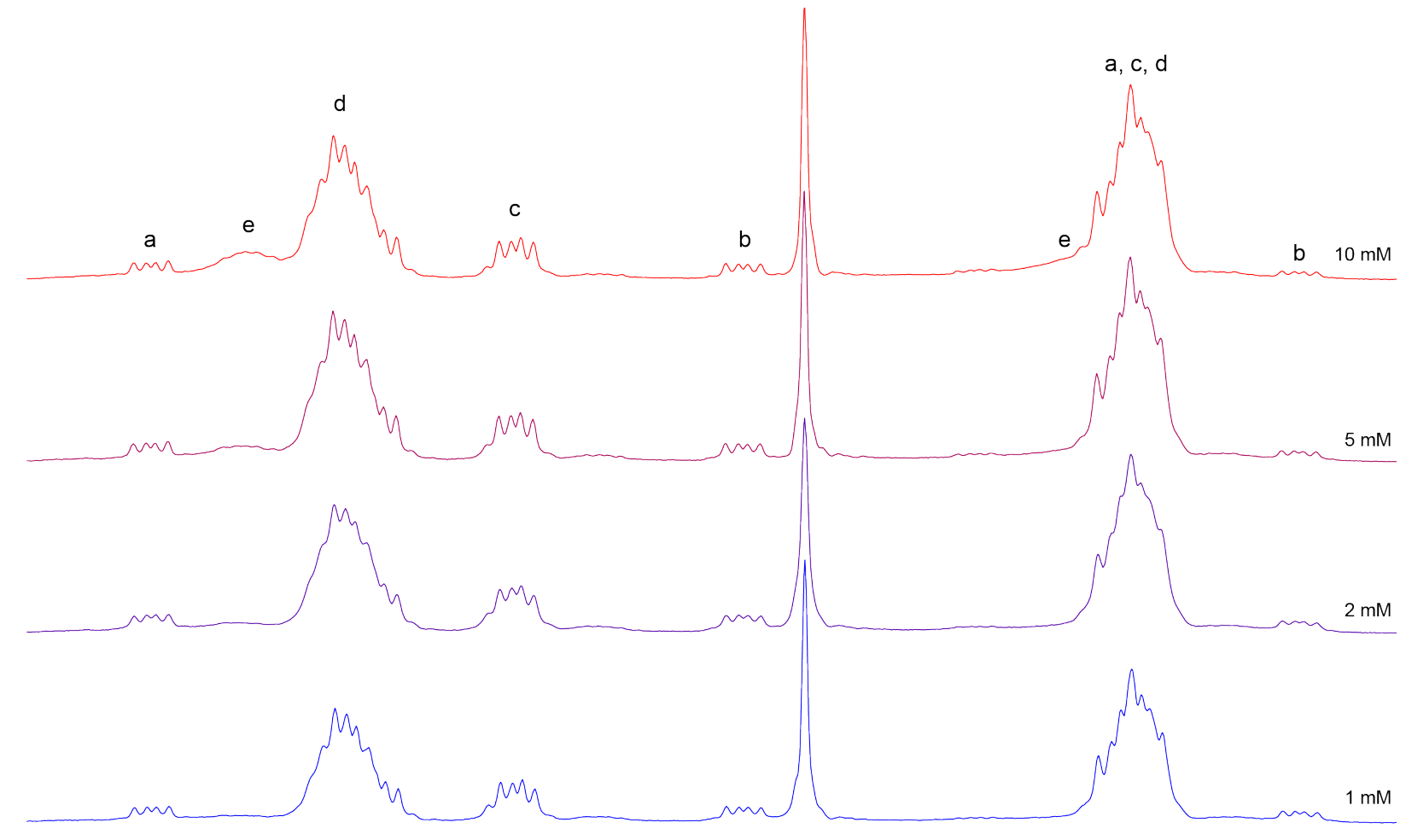

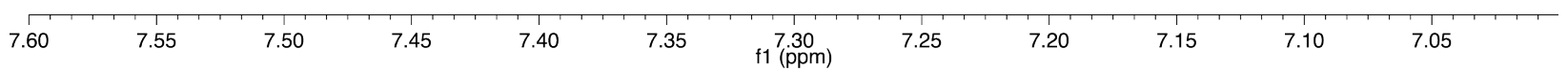

Figure S5. ${ }^{1} \mathrm{H}$ NMR of crude poly-3b prepared at $[3] /[2]=5$ and $[2]=10,5,2$, and $1 \mathrm{mM}$, respectively. With increasing dilution, signals from cyclic species with 2 (a), ${ }^{1} 3$ (b), ${ }^{2} 5$ (c), ${ }^{3}$ and $>5$ (d) monomer units remain consistent, while less linear polymer $(e)$ is formed. 


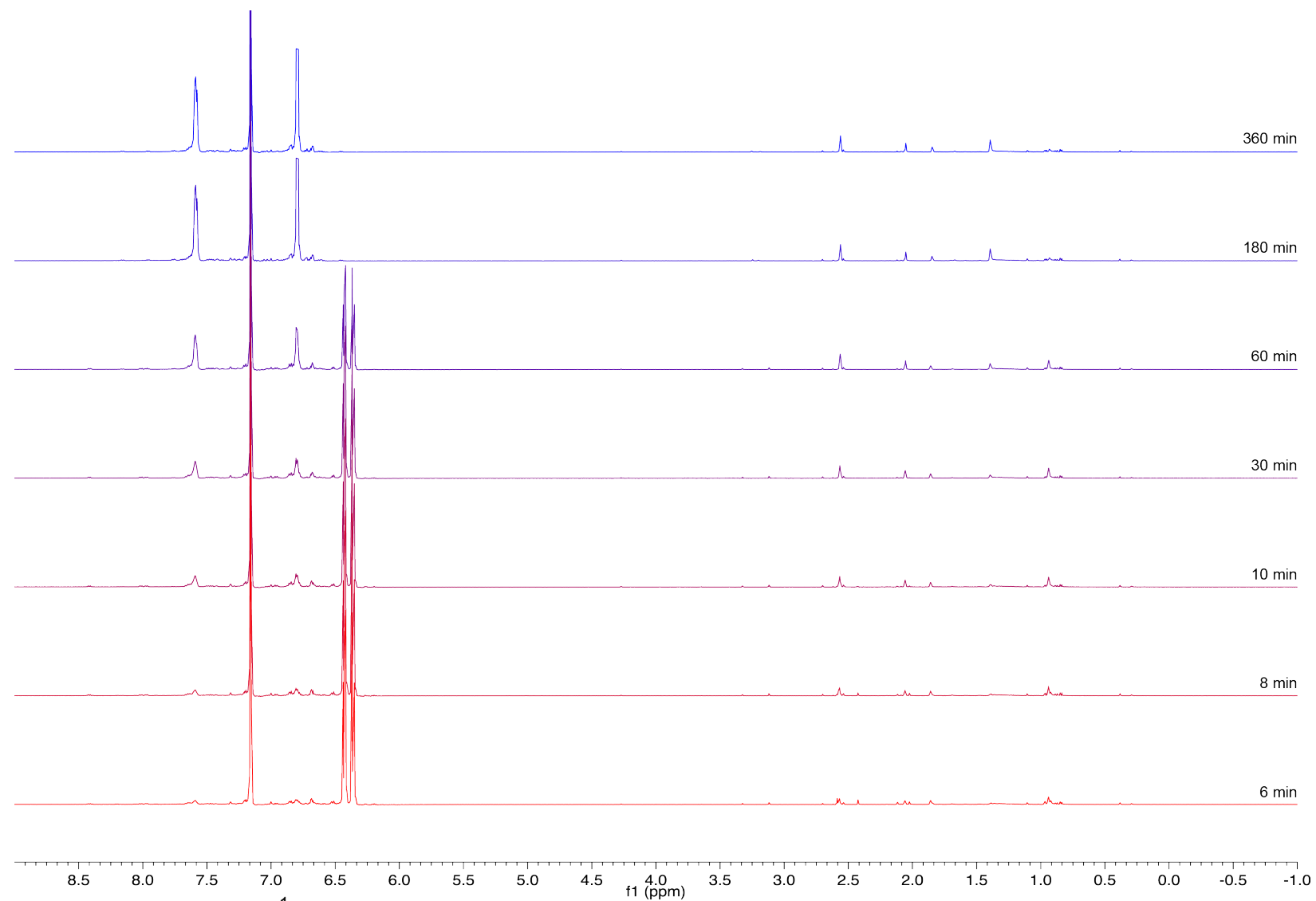

Figure S6. Transient ${ }^{1} \mathrm{H}$ NMR spectra of the polymerization of $3^{*}$ with 1. 


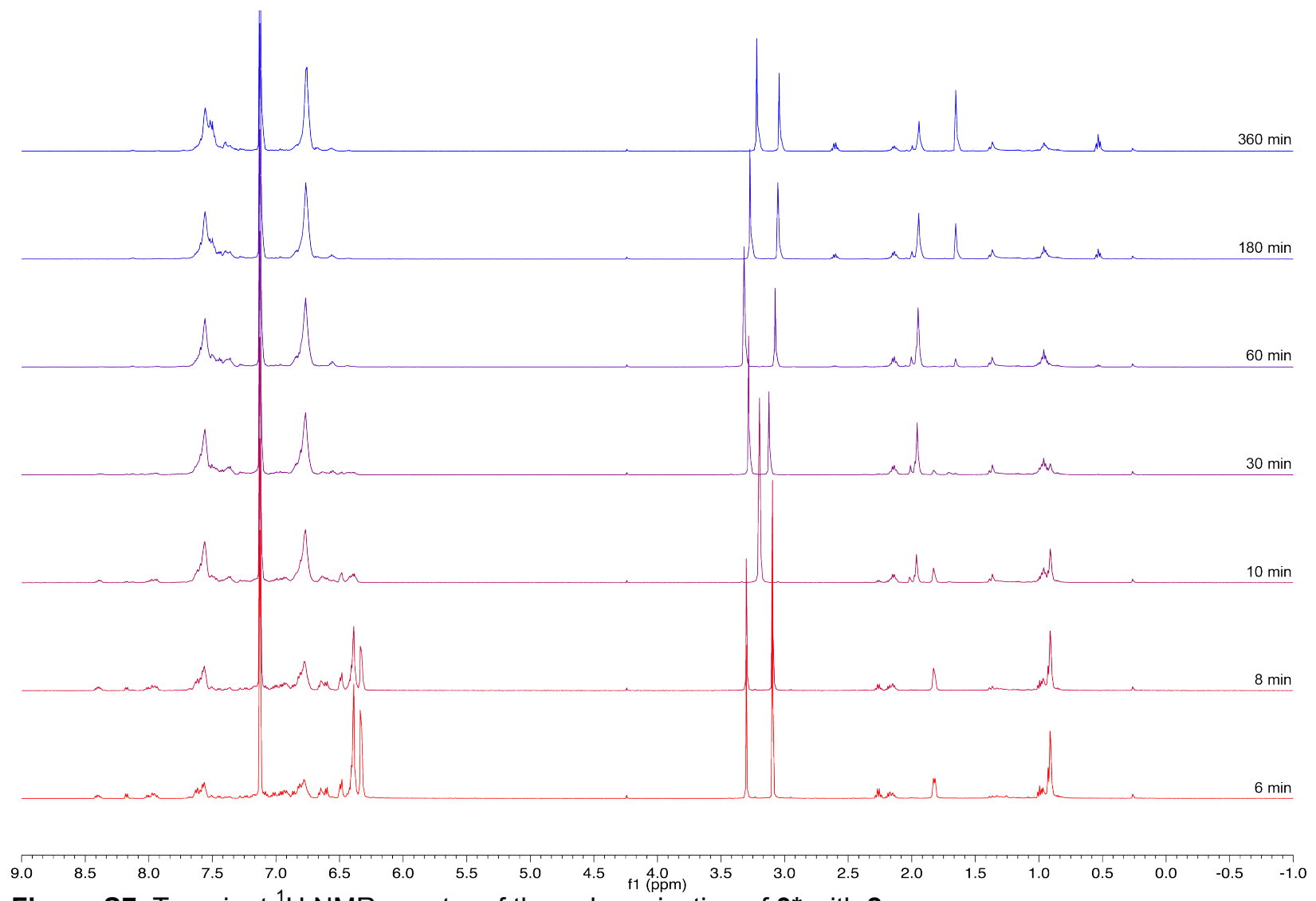

Figure S7. Transient ${ }^{1} \mathrm{H}$ NMR spectra of the polymerization of $3^{*}$ with 2 . 


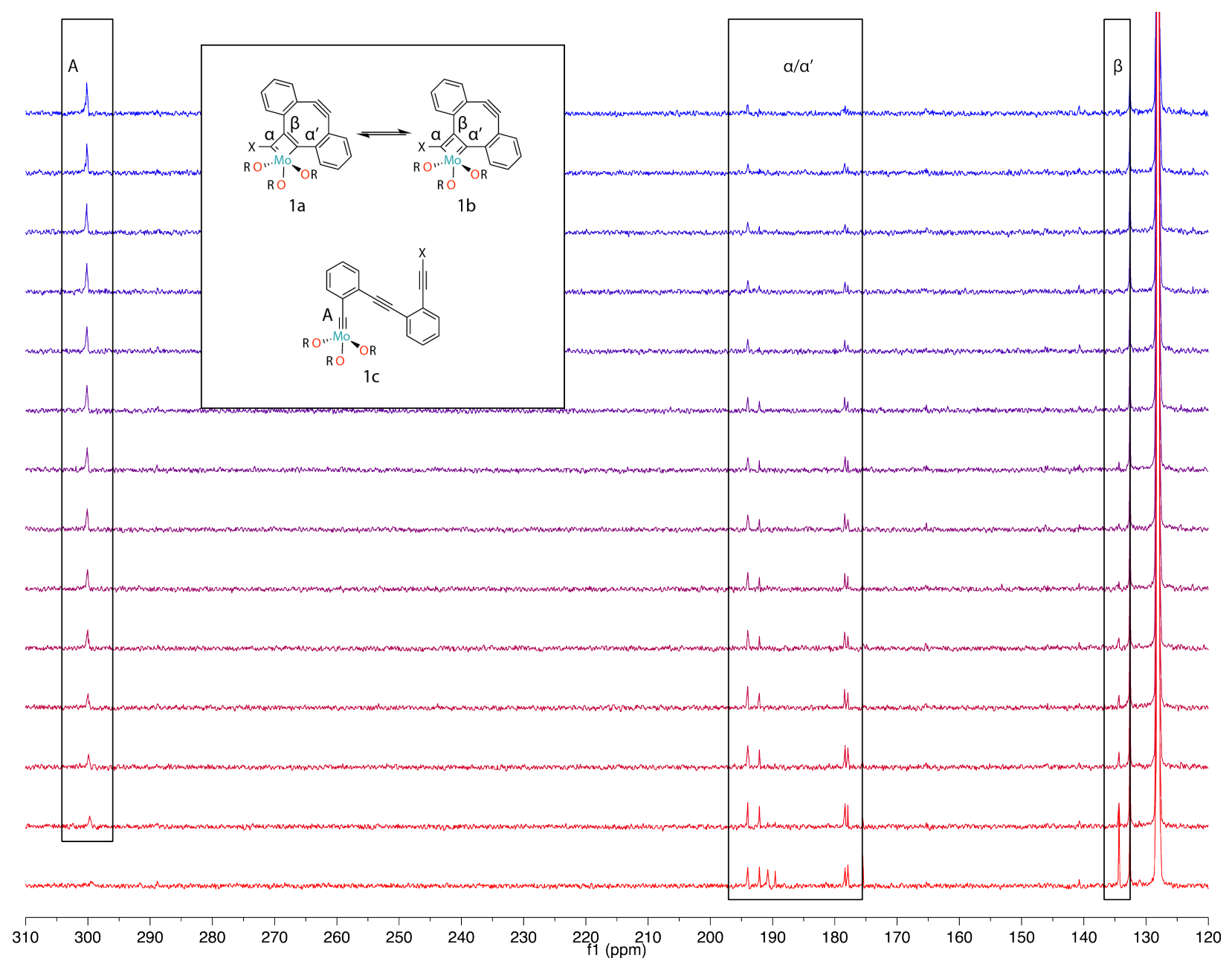

Figure S8. Transient ${ }^{13} \mathrm{C}$ NMR spectra of the polymerization of $3^{*}$ with 1 . Each spectrum is the sum of 7.5 $\min$ of acquisition. The resonances due to the molybdacyclobutadiene intermediate $\left(\alpha / \alpha^{\prime}\right.$ and $\left.\beta\right)$ decay and the polymer-bound carbyne complex 1c (A) grows in following the final cycloreversion after $3^{*}$ is consumed. 


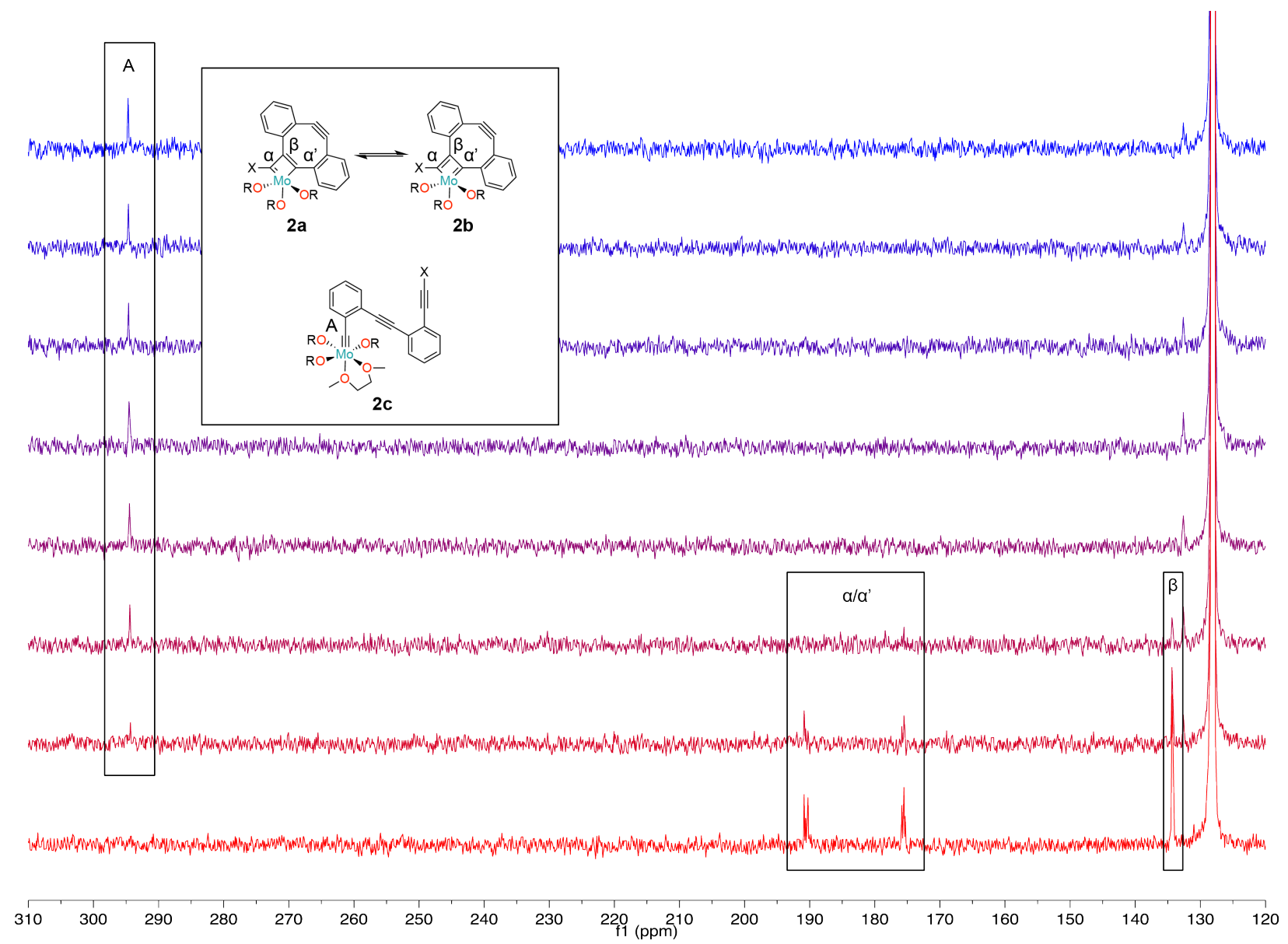

Figure S9. Transient ${ }^{13} \mathrm{C}$ NMR spectra of the polymerization of $3^{*}$ with 2 . Each spectrum is the sum of 7.5 min of acquisition. The resonances due to the molybdacyclobutadiene intermediate $\left(\alpha / \alpha^{\prime}\right.$ and $\beta$ ) decay and the polymer-bound carbyne complex $2 \mathrm{c}(\mathrm{A})$ grows in in following the final cycloreversion after $\mathbf{3}^{*}$ is consumed. 


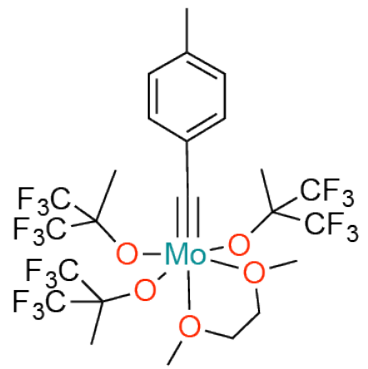

4

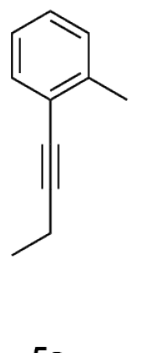

$5 a$

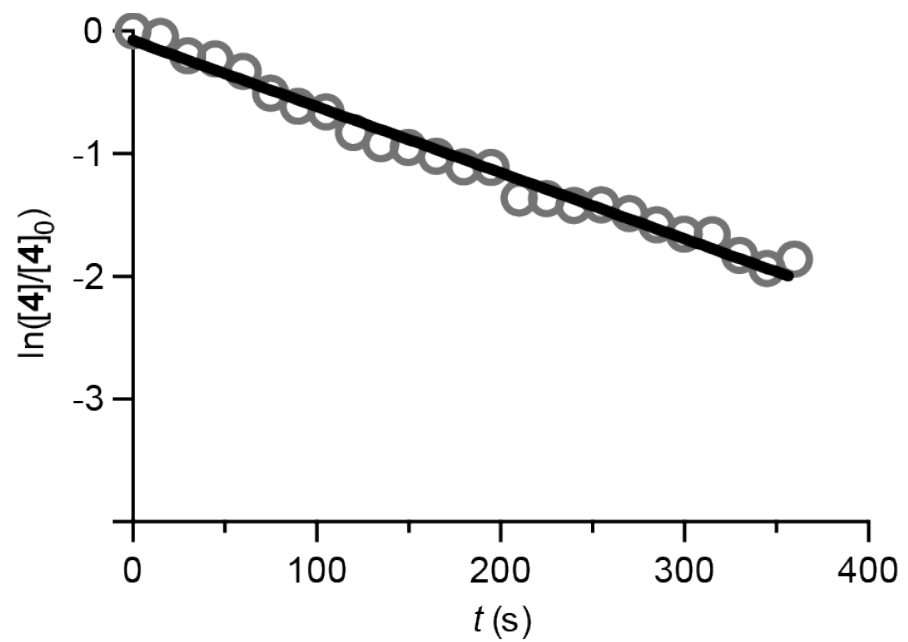

Figure S10. Pseudo-first order reaction of 4 with $\mathbf{5 a}$. [5a] $=41 \mathrm{mM},[4]_{0}=1.9 \mathrm{mM}, \mathrm{R}^{2}=0.963$ 

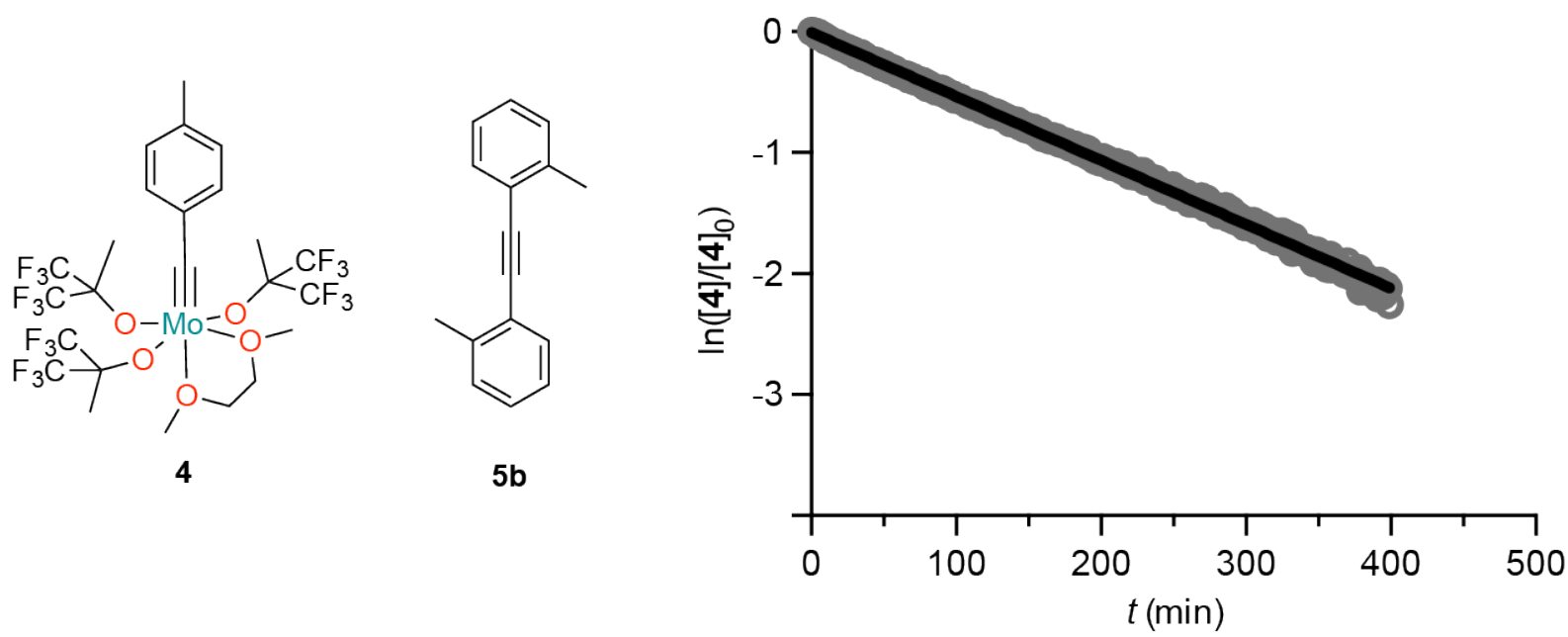

Figure S11. Pseudo-first order reaction of $\mathbf{4}$ with $\mathbf{5 b}$. $[\mathbf{5 b}]=124 \mathrm{mM},[\mathbf{4}]_{0}=1.9 \mathrm{mM}, \mathrm{R}^{2}=0.998$ 
Materials and General Methods. Unless otherwise stated, all manipulations of air and/or moisture sensitive compounds were carried out in oven-dried glassware, under an atmosphere of $\mathrm{Ar}$ or $\mathrm{N}_{2}$. All solvents and reagents were purchased from Alfa Aesar, Spectrum Chemicals, Acros Organics, TCl America, and Sigma-Aldrich and were used as received unless otherwise noted. Organic solvents were dried by passing through a column of alumina and were degassed by vigorous bubbling of $\mathrm{N}_{2}$ or $\mathrm{Ar}$ through the solvent for $20 \mathrm{~min}$. Flash column chromatography was performed on SiliCycle silica gel (particle size 40-63 $\mu \mathrm{m}$ ). Thin layer chromatography was carried out using SiliCycle silica gel $60 \AA$ F-254 precoated plates $\left(0.25 \mathrm{~mm}\right.$ thick) and visualized by UV absorption. All ${ }^{1} \mathrm{H},\left\{{ }^{1} \mathrm{H}\right\}{ }^{13} \mathrm{C}$, and ${ }^{19} \mathrm{~F}$ NMR spectra were recorded on Bruker AV-600, DRX-500, and AV-500 spectrometers, and are referenced to residual solvent peaks $\left(\mathrm{CDCl}_{3}{ }^{1} \mathrm{H}\right.$ NMR $\delta=7.26 \mathrm{ppm},{ }^{13} \mathrm{C}$ NMR $\delta=77.16 \mathrm{ppm} ; \mathrm{C}_{6} \mathrm{D}_{6}{ }^{1} \mathrm{H}$ NMR $\delta=7.16 \mathrm{ppm},{ }^{13} \mathrm{C}$ NMR $\delta=128.06 \mathrm{ppm}$; Tol- $d_{8}{ }^{1} \mathrm{H}$ NMR $\delta=2.08 \mathrm{ppm}$; THF- $d_{8}{ }^{1} \mathrm{H}$ NMR $\delta=1.78 \mathrm{ppm},{ }^{13} \mathrm{C}$ NMR $\delta=67.21$ $\mathrm{ppm})$ or hexafluorobenzene $\left({ }^{19} \mathrm{~F}\right.$ NMR $\left.\delta=-162.90 \mathrm{ppm}\right)$. The concentrations of $\mathbf{4}, \mathbf{5 a}$, and $\mathbf{5 b}$ were determined by ${ }^{1} \mathrm{H}$ and ${ }^{19} \mathrm{~F}$ NMR using the ERETIC method ${ }^{4}$ against an external standard of $18.2 \mathrm{mM}$ 1,3,5-tris(trifluoromethyl)benzene in $\mathrm{C}_{6} \mathrm{D}_{6}$. ESI mass spectrometry was performed on a Finnigan LTQFT (Thermo) spectrometer in positive ionization mode. MALDI mass spectrometry was performed on a Voyager-DE PRO (Applied Biosystems Voyager System 6322) in positive mode using a matrix of dithranol. Elemental analysis (CHN) was performed on a Perkin Elmer 2400 Series II combustion analyzer (values are given in \%). Gel permeation chromatography (GPC) was carried out on a LC/MS Agilent 1260 Infinity set up with a guard and two Agilent Polypore $300 \times 7.5 \mathrm{~mm}$ columns at $35{ }^{\circ} \mathrm{C}$. All GPC analyses were performed on a $0.2 \mathrm{mg} / \mathrm{mL}$ solution of polymer in chloroform. An injection volume of $25 \mu \mathrm{L}$ and a flow rate of $1 \mathrm{~mL} / \mathrm{min}$ were used. Calibration was based on narrow polydispersity polystyrene standards ranging from $M_{\mathrm{w}}=100$ to 4,068,981. X-ray crystallography was performed on APEX II QUAZAR, using a Microfocus Sealed Source (Incoatec I $\mu S$; Mo-Ka radiation), Kappa Geometry with DX (Bruker-AXS build) goniostat, a Bruker APEX II detector, QUAZAR multilayer mirrors as the radiation monochromator, and Oxford Cryostream 700 for 2. Crystallographic data was refined with SHELXL-97, solved with SIR-2007, visualized with ORTEP-32, and finalized with WinGX. UV-Vis absorption spectra were acquired in chloroform solution on a Varian Cary 50 spectrophotometer (Agilent, USA). Fluorescence emissions spectra were acquired at an excitation wavelength of $300 \mathrm{~nm}$ on a Fluoromax-4 spectrofluorometer equipped with automatic polarizers, $1.0 \mathrm{~nm}$ slit widths for excitation/emission and a 0.5 $\mathrm{s}$ integration time. Quantum yields were calibrated to 1,4-bis(5-phenyloxazol-2-yl) benzene (POPOP) in cyclohexane $\left(\Phi_{\mathrm{F}}=0.97\right) .{ }^{5} \mathbf{1},{ }^{6} \mathbf{3}^{4}{ }^{4},{ }^{5}$ and $\mathbf{5} \mathrm{b}^{6}$ were synthesized following literature procedures. 


\section{Synthetic Procedures:}

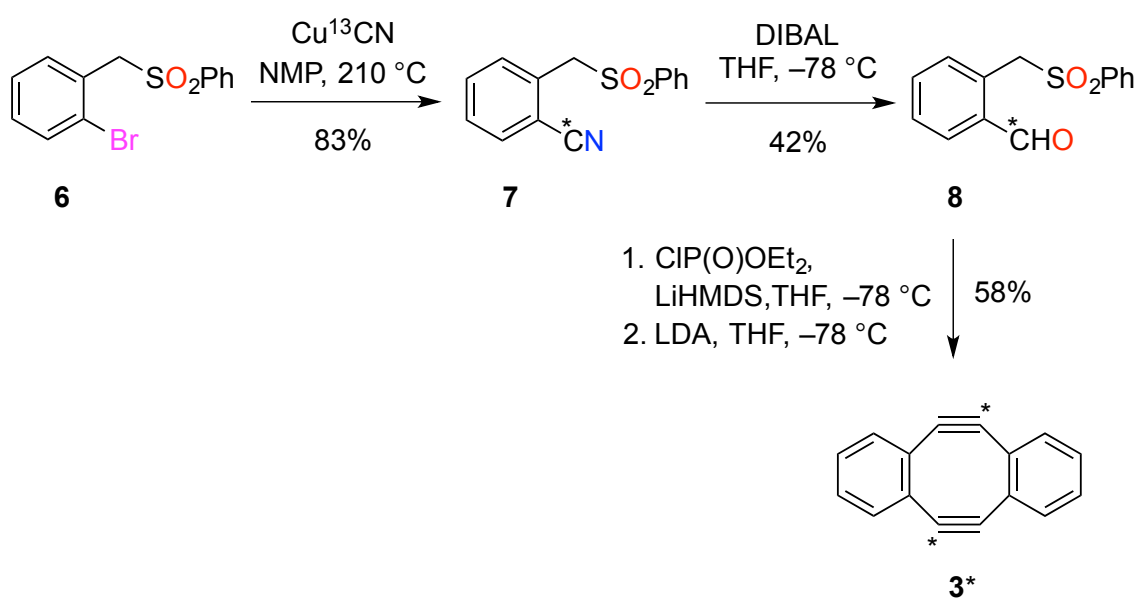

Scheme S1. Synthesis of ${ }^{13} \mathrm{C}$ labeled $3^{*}$.

2-((phenylsulfonyl)methyl)benzonitrile (7) A $50 \mathrm{~mL}$ sealable Schlenk flask was charged under $\mathrm{N}_{2}$ with 1bromo-2((phenylsulfonyl)methyl)benzene $6(1.00 \mathrm{~g}, 3.20 \mathrm{mmol})$, and $\mathrm{Cu}^{13} \mathrm{CN}(0.29 \mathrm{~g}, 3.20 \mathrm{mmol})$ in NMP $(6 \mathrm{~mL}) .^{\mathrm{S} 1, \mathrm{~S} 2}$ The reaction mixture was heated at $210^{\circ} \mathrm{C}$ for $11 \mathrm{~h}$. The reaction mixture was cooled and diluted with $\mathrm{H}_{2} \mathrm{O}(50 \mathrm{~mL})$ and EtOAc $(50 \mathrm{~mL})$, and filtered. The solid residue was washed with $\mathrm{H}_{2} \mathrm{O}(50$ $\mathrm{mL})$ and EtOAc $(50 \mathrm{~mL})$. The filtrate was extracted with EtOAc $(150 \mathrm{~mL})$ and the combined organic phases were washed with saturated aqueous $\mathrm{NaCl}(300 \mathrm{~mL})$, dried over $\mathrm{MgSO}_{4}$, and concentrated on a rotary evaporator. Column chromatography $\left(\mathrm{SiO}_{2} ; \mathrm{CH}_{2} \mathrm{Cl}_{2}(100 \mathrm{~mL})\right.$ then $1: 1$ hexane/ EtOAc) yielded 7 (0.68 g, $2.64 \mathrm{mmol}, 83 \%)$ as a colorless solid. ${ }^{1} \mathrm{H}$ NMR $\left(400 \mathrm{MHz}, \mathrm{CDCl}_{3}, 22{ }^{\circ} \mathrm{C}\right) \delta=7.72-7.63(\mathrm{~m}, 5 \mathrm{H})$, 7.57-7.44 (m, 4H), $4.57(\mathrm{~s}, 2 \mathrm{H}) \mathrm{ppm} ;{ }^{13} \mathrm{C}$ NMR $\left(151 \mathrm{MHz}, \mathrm{CDCl}_{3}, 22{ }^{\circ} \mathrm{C}\right) \delta=137.7,134.4,133.1,132.9$, 132.4, 132.3, 131.8, 129.6, 129.4, 128.9, 116.7, 60.6 ppm; FTMS (ESI-TOF) m/z: $\left.{ }^{12} \mathrm{C}_{13}{ }^{13} \mathrm{C}_{1} \mathrm{H}_{11} \mathrm{NO}_{2} \mathrm{~S}\right]^{+}$ calcd. $\left[{ }^{12} \mathrm{C}_{13}{ }^{13} \mathrm{C}_{1} \mathrm{H}_{11} \mathrm{NO}_{2} \mathrm{~S}\right] 281.0436$; found 281.0438 .

2-((phenylsulfonyl)methyl)benzaldehyde (8) A $100 \mathrm{~mL}$ Schlenk flask was charged under $\mathrm{N}_{2}$ with 7 (0.64 g, $2.30 \mathrm{mmol})$ in THF $(20 \mathrm{~mL})$ and cooled to $-78{ }^{\circ} \mathrm{C}$. DIBAL $(5.80 \mathrm{~mL}$ in hexanes, $5.80 \mathrm{mmol})$ was added dropwise to the reaction mixture. The cold bath was removed and the reaction mixture was stirred at 24 ${ }^{\circ} \mathrm{C}$ for $2.5 \mathrm{~h}$. The reaction mixture was cooled to $0{ }^{\circ} \mathrm{C}$ and quenched with saturated aqueous $\mathrm{NH}_{4} \mathrm{Cl}(300$ $\mathrm{mL})$ and $\mathrm{HCl}(6 \mathrm{M}, 50 \mathrm{~mL})$. The reaction mixture was stirred for $1 \mathrm{~h}$ at $24^{\circ} \mathrm{C}$ diluted with $\mathrm{H}_{2} \mathrm{O}(50 \mathrm{~mL})$ and extracted with EtOAc $(150 \mathrm{~mL})$. The combined organic phases were washed with saturated aqueous $\mathrm{NaCl}(200 \mathrm{~mL})$, dried over $\mathrm{MgSO}_{4}$, and concentrated on a rotary evaporator. Column chromatography $\left(\mathrm{SiO}_{2} ; \mathrm{CH}_{2} \mathrm{Cl}_{2}\right)$ and recrystallization with EtOAc yielded $8(0.25 \mathrm{~g}, 0.96 \mathrm{mmol}, 42 \%)$ as a colorless solid. ${ }^{1} \mathrm{H}$ NMR $\left(300 \mathrm{MHz}, \mathrm{CDCl}_{3}, 22{ }^{\circ} \mathrm{C}\right) \delta=9.82(\mathrm{~d}, \mathrm{~J}=177 \mathrm{~Hz}, 1 \mathrm{H}), 7.76-7.67(\mathrm{~m}, 3 \mathrm{H}), 7.63-7.58(\mathrm{~m}, 3 \mathrm{H})$, 7.48-7.43 (m, 3H), 5.04 (s, 2H) ppm; ${ }^{13} \mathrm{C}$ NMR $\left(151 \mathrm{MHz} \mathrm{CDCl}_{3}, 22{ }^{\circ} \mathrm{C}\right) \delta=192.1,138.3,134.8,134.5$, 134.4, 134.4, 133.9, 133.6, 129.5, 128.9, 128.7, 57.7 ppm; FTMS (ESI-TOF) m/z: $\left[{ }^{12} \mathrm{C}_{13}{ }^{13} \mathrm{C}_{1} \mathrm{H}_{12} \mathrm{O}_{3} \mathrm{NaS}\right]^{+}$ calcd. $\left[{ }^{12} \mathrm{C}_{13}{ }^{13} \mathrm{C}_{1} \mathrm{H}_{12} \mathrm{O}_{3} \mathrm{NaS}\right] 284.0433$; found 284.0436 . 
5,6,11,12-tetradehydrodibenzo[a,e]cyclooctene (3*) A $100 \mathrm{~mL}$ Schlenk flask was charged under $\mathrm{N}_{2}$ with 8 $(0.25 \mathrm{~g}, 0.96 \mathrm{mmol})$ in THF $(30 \mathrm{~mL})$ and cooled to $-78{ }^{\circ} \mathrm{C}$. Diethyl chlorophosphate $(0.17 \mathrm{~mL}, 1.20 \mathrm{mmol})$ and LiHMDS (1 M in THF, $2.00 \mathrm{~mL}, 2.00 \mathrm{mmol}$ ) were added dropwise and the reaction mixture was stirred for $30 \mathrm{~min}$ at $-78{ }^{\circ} \mathrm{C}$ and for $1.5 \mathrm{~h}$ at $24{ }^{\circ} \mathrm{C}$. The reaction mixture was cooed to $-78{ }^{\circ} \mathrm{C}$ and LDA ( 2 $\mathrm{M}$ in THF, $2.50 \mathrm{~mL}, 5.00 \mathrm{mmol}$ ) was added dropwise and stirred at $-78{ }^{\circ} \mathrm{C}$ for $2 \mathrm{~h}$. The reaction mixture was quenched with saturated aqueous $\mathrm{NH}_{4} \mathrm{Cl}(50 \mathrm{~mL})$ and extracted with EtOAc $(150 \mathrm{~mL})$. The combined organic phases were washed with saturated aqueous $\mathrm{NaCl}(200 \mathrm{~mL})$, dried over $\mathrm{MgSO}_{4}$, and concentrated on a rotary evaporator. Column chromatography $\left(\mathrm{SiO}_{2} ; 2: 3 \mathrm{CH}_{2} \mathrm{Cl}_{2} /\right.$ hexane) yielded 3* (55 $\mathrm{mg}, 0.27 \mathrm{mmol}, 58 \%)$ as a yellow solid. ${ }^{1} \mathrm{H}$ NMR $\left(400 \mathrm{MHz}, \mathrm{CDCl}_{3}, 22{ }^{\circ} \mathrm{C}\right) \delta=6.95-6.91(\mathrm{~m}, 4 \mathrm{H}), 6.75-$ $6.72(\mathrm{~m}, 4 \mathrm{H}) \mathrm{ppm} ;{ }^{13} \mathrm{C}$ NMR $\left(101 \mathrm{MHz}, \mathrm{CDCl}_{3}, 22{ }^{\circ} \mathrm{C}\right) \delta=133.1,129.2,127.5,109.5$ ppm. FTMS (ElTOF) $\mathrm{m} / \mathrm{z}:\left[{ }^{12} \mathrm{C}_{14}{ }^{13} \mathrm{C}_{2} \mathrm{H}_{8}\right]^{+}$calcd. $\left[{ }^{12} \mathrm{C}_{14}{ }^{13} \mathrm{C}_{2} \mathrm{H}_{8}\right]$ 202.0693; found 202.0698 .

1-(but-1-yn-1-yl)-2-methylbenzene (5a) A $50 \mathrm{~mL}$ Schlenk flask was charged with 1-butyne (4 mL, 50 $\mathrm{mmol})$, 2-iodotoluene $(1.5 \mathrm{~mL}, 11.8 \mathrm{mmol})$, triethylamine $(3.1 \mathrm{~mL}, 22.5 \mathrm{mmol}), \mathrm{PdCl}_{2}\left(\mathrm{PPh}_{3}\right)_{2}(156 \mathrm{mg}$, $0.23 \mathrm{mmol})$, and Cul $(73 \mathrm{mg}, 0.38 \mathrm{mmol})$ in dry THF $(30 \mathrm{~mL})$ under $\mathrm{N}_{2}$ at $-78{ }^{\circ} \mathrm{C}$. The reaction mixture was stirred at $22{ }^{\circ} \mathrm{C}$ for $24 \mathrm{~h}$. The reaction mixture was poured into hexanes $(50 \mathrm{~mL})$ and filtered through celite. Vacuum distillation yielded $5 \mathrm{a}(1.56 \mathrm{~g}, 10.8 \mathrm{mmol}, 92 \%)$ as a yellow oil. b.p. $42-44{ }^{\circ} \mathrm{C}(1 \mathrm{torr}) ;{ }^{1} \mathrm{H}$ $\operatorname{NMR}\left(500 \mathrm{MHz}, \mathrm{CDCl}_{3}, 22{ }^{\circ} \mathrm{C}\right) \delta=7.37(\mathrm{~d}, J=7.5 \mathrm{~Hz}, 1 \mathrm{H}), 7.21-7.14(\mathrm{~m}, 2 \mathrm{H}), 7.14-7.08(\mathrm{~m}, 1 \mathrm{H}), 2.47$ (q, $J=7.5 \mathrm{~Hz}, 2 \mathrm{H}), 2.43(\mathrm{~s}, 3 \mathrm{H}), 1.27$ (t, $J=7.5 \mathrm{~Hz}, 3 \mathrm{H}) \mathrm{ppm} ;{ }^{13} \mathrm{C} \mathrm{NMR}\left(126 \mathrm{MHz}, \mathrm{CDCl}_{3}, 22{ }^{\circ} \mathrm{C}\right) \delta=$ 140.0, 131.9, 129.4, 127.6, 125.5, 123.9, 95.8, 78.9, 20.8, 14.3, 13.4 ppm; FTMS (El-TOF) m/z: $\left[\mathrm{C}_{11} \mathrm{H}_{12}\right]^{+}$ calcd. $\left[\mathrm{C}_{11} \mathrm{H}_{12}\right] 144.0939$; found 144.0939 


\section{Loading Experiments}

The monomer loading experiment of the polymerization of $\mathbf{3}$ with $\mathbf{1}$ consisted of the following

- Stock solution of monomer $3(100 \mathrm{mM})$ in $\mathrm{C}_{6} \mathrm{D}_{6}$

- Stock solution of the catalyst $1(6.67 \mathrm{mM})$ in $\mathrm{C}_{6} \mathrm{D}_{6}$

A J. Young NMR tube was charged with $C_{6} D_{6}(0,150$, or $200 \mu \mathrm{L})$, followed by an aliquot of catalyst 1 stock solution (300, 150, or $100 \mu \mathrm{L}$, respectively), and monomer 3 stock solution $(200 \mu \mathrm{L}) .{ }^{1} \mathrm{H}$ NMR were recorded at $22{ }^{\circ} \mathrm{C}$. After consumption of the monomer, the polymer was precipitated with $\mathrm{MeOH}(500 \mu \mathrm{L})$, filtered, and the solid residue dried under vacuum overnight. The polymers were characterized by size exclusion GPC and ${ }^{1} \mathrm{H}$ and ${ }^{13} \mathrm{C}$ NMR. The degree of polymerization was determined by integrating the peak $\left(\mathrm{C}_{(A r)}-\mathrm{H}\right)$ of the polymer at $7.50 \mathrm{ppm}$ to the peak $\left(\mathrm{C}_{(A r)}-\mathrm{H}\right)$ of the mesityl end-group at $6.81 \mathrm{ppm}$.

\section{Monomer Conversion vs. $M_{\mathrm{n}}$}

Monomer $3(12 \mathrm{mg})$ was dissolved in of $\mathrm{C}_{6} \mathrm{D}_{6}(600 \mu \mathrm{L})$, and catalyst $1(2 \mathrm{mg})$ was dissolved in $\mathrm{C}_{6} \mathrm{D}_{6}(500$ $\mu \mathrm{L})$. HMDSO $(6 \mu \mathrm{L})$ was added to the solution of monomer 1 . An aliquot of the monomer solution $(100 \mu \mathrm{L})$ was diluted with $\mathrm{C}_{6} \mathrm{D}_{6}(300 \mu \mathrm{L})$, to obtain the initial ${ }^{1} \mathrm{H}$ NMR integration ratio of the monomer multiplet at $6.45 \mathrm{ppm}$ to the HMDSO singlet at $0.12 \mathrm{ppm}$. The solution of catalyst was added to the remaining $500 \mu \mathrm{L}$ solution of monomer. At different time-points, $200 \mu \mathrm{L}$ aliquots of the reaction were diluted with $\mathrm{C}_{6} \mathrm{D}_{6}(200$ $\mu \mathrm{L})$ and quenched with $\mathrm{CD}_{3} \mathrm{OD}(60 \mu \mathrm{L})$. After obtaining a ${ }^{1} \mathrm{H} N \mathrm{NMR}$, the polymer was precipitated with $\mathrm{MeOH}(500 \mu \mathrm{L})$, filtered, and dried under vacuum overnight. The polymers were characterized by size exclusion GPC.

\section{Concentration dependence of cyclic polymer selectivity of catalyst 2}

A stock solution of monomer $3(200 \mu \mathrm{L}$ at $125 \mathrm{mM}, 0.025 \mathrm{mmol})$ in toluene was diluted with an appropriate volume of toluene $(600 \mu \mathrm{L}, 1.6 \mathrm{~mL}, 3.6 \mathrm{~mL}, 7.6 \mathrm{~mL})$ to give the desired monomer concentration. To each was added $200 \mu \mathrm{L}$ of a $25 \mathrm{mM}$ solution of 2 in toluene at room temperature with stirring. The polymerizations were stirred for 16 hours and then the catalyst deactivated by the addition of methanol ( $3 x$ the solution volume). The crude polymers were concentrated by rotary evaporation to a tan solid and dried in vacuum overnight. The solids were dissolved in chloroform and the percent linear polymer ( ${ }^{1} \mathrm{H}$ NMR) and MW (GPC) were determined.

\section{In-situ NMR studies of the polymerization of 3}

A typical experiment consists of the following. To a solution of $3(5 \mathrm{mg}, 0.025 \mathrm{mmol})$ in $\mathrm{C}_{6} \mathrm{D}_{6}(0.3 \mathrm{~mL})$ in an $\mathrm{N}_{2}$ glovebox was added a solution of the appropriate amount of 1 or 2 in $\mathrm{C}_{6} \mathrm{D}_{6}(0.2 \mathrm{~mL})$. The mixture was immediately transferred to a J. Young tube and frozen. The reaction mixture was thawed and the reaction followed by NMR spectroscopy. The concentrations of the different catalyst species were 
determined by integrating the methyl $\left({ }^{1} \mathrm{H}\right)$ or trifluoromethyl $\left({ }^{19} \mathrm{~F}\right)$ resonances corresponding to the $\mathrm{OC}\left(\mathrm{CH}_{3}\right)\left(\mathrm{CF}_{3}\right)_{2}$ ligands.

\section{Cross metathesis rate studies with model complex 4:}

A stock solution of $4(20 \mathrm{mM})$ in $\mathrm{C}_{6} \mathrm{D}_{6}$ was prepared.

With $5 \mathrm{a}$ : For the reaction with $5 \mathrm{a}, 50 \mu \mathrm{L}$ of the stock solution of 4 was diluted with $450 \mu \mathrm{L} \mathrm{C}_{6} \mathrm{D}_{6}$ in a septum-capped NMR tube under $\mathrm{N}_{2}$. The tube was placed in the NMR spectrometer and allowed to reach temperature equilibrium at $298 \mathrm{~K}$, then neat $5 \mathrm{a}$ (20 equiv) was injected and the reaction monitored by NMR. The concentration of $5 \mathrm{a}$ was verified by ERETIC. The disappearance of 4 was fit to a pseudo-first order decay over the first 2.5 half-lives $(<5 \%$ change in $[5 a])$ by fitting a line to $\ln \left([4] /[4]_{0}\right)$ vs. $t$. Dividing the slope by $[\mathbf{5 a}]_{0}$, as determined by ERETIC, provides $k$.

With 5b: A J. Young tube was charged with $50 \mu \mathrm{L}$ of stock solution of 4 and 65 equiv $\mathbf{5 b}$ in $\mathrm{C}_{6} \mathrm{D}_{6}(450 \mu \mathrm{L})$. The tube was placed in the NMR spectrometer and allowed to reach temperature equilibrium, at which point [4] and [5b] were determined by ERETIC. The disappearance of $\mathbf{4}$ was fit to a pseudo-first order decay over the first three half-lives $\left(<2 \%\right.$ change in [5b]) by fitting a line to $\ln \left([4] /[4]_{0}\right)$ vs. $t$. Dividing the slope by $[5 b]_{0}$, as determined by ERETIC, provides $k$. 


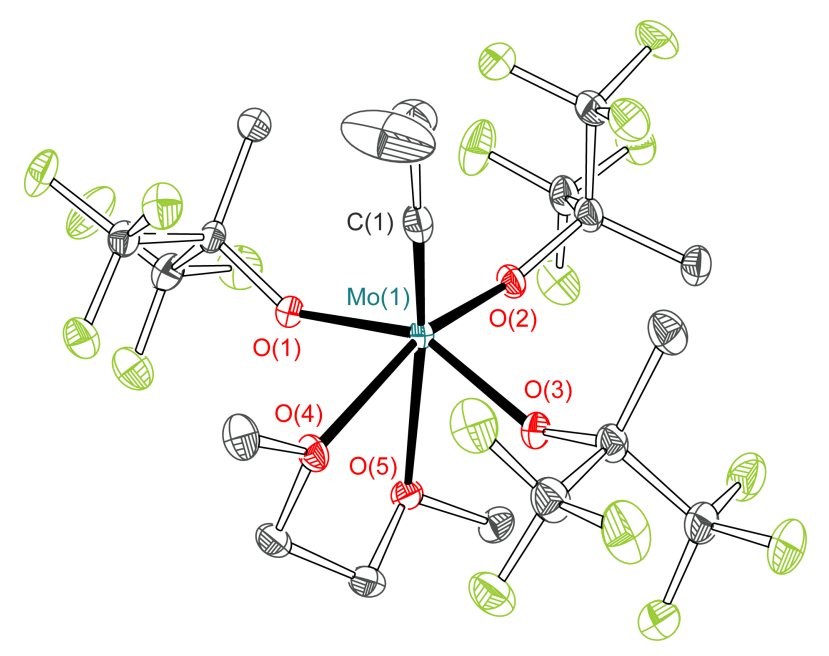

Table S2. Crystal data and structure refinement for 2. ORTEP thermal ellipsoids are at the $50 \%$ probability level. Color coding: C (gray), O (red), F (green), Mo (turquoise). Hydrogen atoms are omitted for clarity.

CCDC no.

Empirical formula

Formula weight

Temperature

Wavelength

Crystal system

Space group

Unit cell dimensions

Volume

Z

Density (calculated)

Absorption coefficient

$\mathrm{F}(000)$

Crystal size

Theta range for data collection

Index ranges

Reflections collected

Independent reflections

Completeness to theta $=25.00^{\circ}$

Absorption correction

Max. and min. transmission

Refinement method

Data / restraints / parameters

Goodness-of-fit on $\mathrm{F}^{2}$

Final $R$ indices [ $>2$ sigma(I)]

$R$ indices (all data)

Largest diff. peak and hole
1456633

$\mathrm{C}_{19} \mathrm{H}_{24} \mathrm{~F}_{18} \mathrm{MoO}_{5}$

770.32

$100(2) \mathrm{K}$

$0.71073 \AA$

Monoclinic

P2(1)/n

$a=11.4678(9) \AA$

$b=16.8911(14) \AA$

$c=13.8634(11) \AA$

2684.8(4) $\AA^{3}$

4

$1.906 \mathrm{Mg} / \mathrm{m}^{3}$

$0.644 \mathrm{~mm}^{-1}$

1528

$0.160 \times 0.160 \times 0.080 \mathrm{~mm}^{3}$

1.901 to $25.387^{\circ}$.

$-13 \leq h \leq 13,-20 \leq k \leq 20,-16 \leq 1 \leq 16$

72070

$4933[\mathrm{R}$ (int) $=0.0277]$

$100.0 \%$

Semi-empirical from equivalents

0.9561 and 0.8355

Full-matrix least-squares on $\mathrm{F}^{2}$

4933 / 0 / 393

1.179

$\mathrm{R} 1=0.0262, w R 2=0.0556$

$\mathrm{R} 1=0.0316, \mathrm{wR} 2=0.0601$

0.386 and -0.476 e $\AA^{-3}$ 
Table S3. Atomic coordinates $\left(\times 10^{4}\right)$ and equivalent isotropic displacement parameters $\left(\AA^{2} \times 10^{3}\right)$ for 2 . $\mathrm{U}(\mathrm{eq})$ is defined as one third of the trace of the orthogonalized $\mathrm{U}^{\mathrm{ij}}$ tensor.

\begin{tabular}{|c|c|c|c|c|}
\hline & $x$ & $y$ & $z$ & $\mathrm{U}(\mathrm{eq})$ \\
\hline$\overline{C(1)}$ & $6515(2)$ & $2284(1)$ & $2591(2)$ & $20(1)$ \\
\hline$C(2)$ & $6652(2)$ & 2091(2) & $3632(2)$ & $29(1)$ \\
\hline$C(3)$ & $7690(4)$ & $1615(2)$ & $3900(2)$ & $68(1)$ \\
\hline $\mathrm{C}(4)$ & $8786(2)$ & $3316(1)$ & $1395(2)$ & 19(1) \\
\hline$C(5)$ & $9647(2)$ & $2618(2)$ & 1312(2) & $25(1)$ \\
\hline$C(6)$ & $9164(2)$ & $3999(2)$ & 733(2) & $25(1)$ \\
\hline$C(7)$ & $8788(2)$ & $3598(2)$ & $2442(2)$ & $25(1)$ \\
\hline$C(8)$ & $5016(2)$ & $4132(1)$ & 1988(2) & 19(1) \\
\hline $\mathrm{C}(9)$ & $3755(2)$ & $4326(1)$ & $1663(2)$ & $23(1)$ \\
\hline$C(10)$ & $5071(2)$ & $3992(1)$ & $3083(2)$ & $22(1)$ \\
\hline$C(11)$ & $5786(2)$ & $4840(1)$ & $1747(2)$ & $23(1)$ \\
\hline$C(12)$ & $4088(2)$ & 1362(1) & $1503(2)$ & $16(1)$ \\
\hline$C(13)$ & $4603(2)$ & $543(1)$ & $1735(2)$ & 19(1) \\
\hline$C(14)$ & $3104(2)$ & 1283(1) & $734(2)$ & $22(1)$ \\
\hline$C(15)$ & $3588(2)$ & 1716(1) & $2417(2)$ & $23(1)$ \\
\hline$C(16)$ & $7714(2)$ & $822(1)$ & $1146(2)$ & $23(1)$ \\
\hline$C(17)$ & $6912(2)$ & 1389(1) & $-309(2)$ & $21(1)$ \\
\hline$C(18)$ & $6902(2)$ & 2174(1) & $-814(2)$ & 21(1) \\
\hline$C(19)$ & $6026(2)$ & $3443(1)$ & $-766(2)$ & $22(1)$ \\
\hline$F(1)$ & $9648(1)$ & $2290(1)$ & $435(1)$ & $31(1)$ \\
\hline$F(2)$ & $9380(1)$ & $2043(1)$ & 1934(1) & $31(1)$ \\
\hline$F(3)$ & 10749(1) & 2833(1) & $1525(1)$ & $39(1)$ \\
\hline$F(4)$ & $9217(1)$ & $3783(1)$ & $-194(1)$ & $32(1)$ \\
\hline$F(5)$ & $8392(1)$ & $4591(1)$ & $773(1)$ & $33(1)$ \\
\hline$F(6)$ & 10204(1) & $4301(1)$ & $984(1)$ & $38(1)$ \\
\hline$F(7)$ & $3694(1)$ & $4420(1)$ & $706(1)$ & $31(1)$ \\
\hline$F(8)$ & $3001(1)$ & $3759(1)$ & $1890(1)$ & $37(1)$ \\
\hline$F(9)$ & $3366(1)$ & $5003(1)$ & 2044(1) & $32(1)$ \\
\hline$F(10)$ & $4517(1)$ & $3339(1)$ & $3356(1)$ & $28(1)$ \\
\hline$F(11)$ & $4609(1)$ & $4599(1)$ & $3578(1)$ & $33(1)$ \\
\hline$F(12)$ & $6182(1)$ & $3930(1)$ & $3398(1)$ & $28(1)$ \\
\hline$F(13)$ & $2637(1)$ & 1989(1) & $548(1)$ & $31(1)$ \\
\hline$F(14)$ & $3474(1)$ & $996(1)$ & $-104(1)$ & $29(1)$ \\
\hline$F(15)$ & $2234(1)$ & $811(1)$ & 1016(1) & $41(1)$ \\
\hline$F(16)$ & $3814(1)$ & $37(1)$ & $2086(1)$ & $29(1)$ \\
\hline$F(17)$ & $5068(1)$ & 191(1) & $966(1)$ & $25(1)$ \\
\hline$F(18)$ & $5461(1)$ & $603(1)$ & $2403(1)$ & $26(1)$ \\
\hline$O(1)$ & $4926(1)$ & $1829(1)$ & 1072(1) & $16(1)$ \\
\hline $\mathrm{O}(2)$ & $5339(1)$ & $3470(1)$ & $1467(1)$ & 18(1) \\
\hline $\mathrm{O}(3)$ & 7701(1) & $3078(1)$ & 1035(1) & $17(1)$ \\
\hline $\mathrm{O}(4)$ & 7213(1) & 1518(1) & $702(1)$ & 18(1) \\
\hline$O(5)$ & $6041(1)$ & $2659(1)$ & $-370(1)$ & $17(1)$ \\
\hline $\mathrm{Mo}(1)$ & $6262(1)$ & $2515(1)$ & $1385(1)$ & 13(1) \\
\hline
\end{tabular}


Table S4. Bond lengths $[\AA]$ and angles $\left[^{\circ}\right]$ for 2.

\begin{tabular}{|c|c|}
\hline$\overline{C(1)-C(2)}$ & $1.485(3)$ \\
\hline $\mathrm{C}(1)-\mathrm{Mo}(1)$ & $1.736(2)$ \\
\hline$C(2)-C(3)$ & $1.477(4)$ \\
\hline $\mathrm{C}(2)-\mathrm{H}(14 \mathrm{~A})$ & 0.9900 \\
\hline $\mathrm{C}(2)-\mathrm{H}(14 \mathrm{~B})$ & 0.9900 \\
\hline $\mathrm{C}(3)-\mathrm{H}(15 \mathrm{~A})$ & 0.9800 \\
\hline $\mathrm{C}(3)-\mathrm{H}(15 \mathrm{~B})$ & 0.9800 \\
\hline $\mathrm{C}(3)-\mathrm{H}(15 \mathrm{C})$ & 0.9800 \\
\hline $\mathrm{C}(4)-\mathrm{O}(3)$ & $1.390(3)$ \\
\hline$C(4)-C(7)$ & $1.528(3)$ \\
\hline$C(4)-C(6)$ & $1.542(3)$ \\
\hline$C(4)-C(5)$ & $1.543(3)$ \\
\hline$C(5)-F(1)$ & $1.336(3)$ \\
\hline$C(5)-F(2)$ & $1.339(3)$ \\
\hline$C(5)-F(3)$ & $1.343(3)$ \\
\hline$C(6)-F(6)$ & $1.337(3)$ \\
\hline$C(6)-F(5)$ & $1.338(3)$ \\
\hline$C(6)-F(4)$ & $1.339(3)$ \\
\hline $\mathrm{C}(7)-\mathrm{H}(5 \mathrm{~A})$ & 0.9800 \\
\hline $\mathrm{C}(7)-\mathrm{H}(5 \mathrm{~B})$ & 0.9800 \\
\hline $\mathrm{C}(7)-\mathrm{H}(5 \mathrm{C})$ & 0.9800 \\
\hline $\mathrm{C}(8)-\mathrm{O}(2)$ & $1.387(3)$ \\
\hline$C(8)-C(11)$ & $1.526(3)$ \\
\hline$C(8)-C(10)$ & $1.536(3)$ \\
\hline $\mathrm{C}(8)-\mathrm{C}(9)$ & $1.541(3)$ \\
\hline$C(9)-F(8)$ & $1.333(3)$ \\
\hline $\mathrm{C}(9)-\mathrm{F}(7)$ & $1.336(3)$ \\
\hline$C(9)-F(9)$ & $1.341(3)$ \\
\hline$C(10)-F(10)$ & $1.332(3)$ \\
\hline$C(10)-F(12)$ & $1.344(3)$ \\
\hline$C(10)-F(11)$ & $1.348(3)$ \\
\hline $\mathrm{C}(11)-\mathrm{H}(9 \mathrm{~A})$ & 0.9800 \\
\hline $\mathrm{C}(11)-\mathrm{H}(9 \mathrm{~B})$ & 0.9800 \\
\hline $\mathrm{C}(11)-\mathrm{H}(9 \mathrm{C})$ & 0.9800 \\
\hline $\mathrm{C}(12)-\mathrm{O}(1)$ & $1.388(3)$ \\
\hline$C(12)-C(15)$ & $1.524(3)$ \\
\hline$C(12)-C(13)$ & $1.536(3)$ \\
\hline$C(12)-C(14)$ & $1.543(3)$ \\
\hline$C(13)-F(17)$ & $1.340(3)$ \\
\hline $\mathrm{C}(13)-\mathrm{F}(18)$ & $1.342(3)$ \\
\hline$C(13)-F(16)$ & $1.342(3)$ \\
\hline$C(14)-F(13)$ & $1.331(3)$ \\
\hline$C(14)-F(14)$ & $1.337(3)$ \\
\hline$C(14)-F(15)$ & $1.341(3)$ \\
\hline $\mathrm{C}(15)-\mathrm{H}(13 \mathrm{~A})$ & 0.9800 \\
\hline $\mathrm{C}(15)-\mathrm{H}(13 \mathrm{~B})$ & 0.9800 \\
\hline $\mathrm{C}(15)-\mathrm{H}(13 \mathrm{C})$ & 0.9800 \\
\hline $\mathrm{C}(16)-\mathrm{O}(4)$ & $1.442(3)$ \\
\hline $\mathrm{C}(16)-\mathrm{H}(16 \mathrm{~A})$ & 0.9800 \\
\hline $\mathrm{C}(16)-\mathrm{H}(16 \mathrm{~B})$ & 0.9800 \\
\hline $\mathrm{C}(16)-\mathrm{H}(16 \mathrm{C})$ & 0.9800 \\
\hline $\mathrm{C}(17)-\mathrm{O}(4)$ & $1.453(3)$ \\
\hline$C(17)-C(18)$ & $1.499(3)$ \\
\hline $\mathrm{C}(17)-\mathrm{H}(17 \mathrm{~A})$ & 0.9900 \\
\hline
\end{tabular}




\begin{tabular}{|c|c|}
\hline $\mathrm{C}(17)-\mathrm{H}(17 \mathrm{~B})$ & 0.9900 \\
\hline $\mathrm{C}(18)-\mathrm{O}(5)$ & $1.431(3)$ \\
\hline $\mathrm{C}(18)-\mathrm{H}(18 \mathrm{~A})$ & 0.9900 \\
\hline $\mathrm{C}(18)-\mathrm{H}(18 \mathrm{~B})$ & 0.9900 \\
\hline $\mathrm{C}(19)-\mathrm{O}(5)$ & $1.434(3)$ \\
\hline $\mathrm{C}(19)-\mathrm{H}(19 \mathrm{~A})$ & 0.9800 \\
\hline $\mathrm{C}(19)-\mathrm{H}(19 \mathrm{~B})$ & 0.9800 \\
\hline $\mathrm{C}(19)-\mathrm{H}(19 \mathrm{C})$ & 0.9800 \\
\hline $\mathrm{O}(1)-\mathrm{Mo}(1)$ & $1.9632(15$ \\
\hline $\mathrm{O}(2)-\mathrm{Mo}(1)$ & $1.9326(15$ \\
\hline $\mathrm{O}(3)-\mathrm{Mo}(1)$ & $1.9740(15$ \\
\hline $\mathrm{O}(4)-\mathrm{Mo}(1)$ & $2.2283(15$ \\
\hline $\mathrm{O}(5)-\mathrm{Mo}(1)$ & $2.4526(15$ \\
\hline $\mathrm{C}(2)-\mathrm{C}(1)-\mathrm{Mo}(1)$ & $176.44(19)$ \\
\hline$C(3)-C(2)-C(1)$ & $115.7(2)$ \\
\hline $\mathrm{C}(3)-\mathrm{C}(2)-\mathrm{H}(14 \mathrm{~A})$ & 108.4 \\
\hline $\mathrm{C}(1)-\mathrm{C}(2)-\mathrm{H}(14 \mathrm{~A})$ & 108.4 \\
\hline $\mathrm{C}(3)-\mathrm{C}(2)-\mathrm{H}(14 \mathrm{~B})$ & 108.4 \\
\hline $\mathrm{C}(1)-\mathrm{C}(2)-\mathrm{H}(14 \mathrm{~B})$ & 108.4 \\
\hline$H(14 A)-C(2)-H(14 B)$ & 107.4 \\
\hline$C(2)-C(3)-H(15 A)$ & 109.5 \\
\hline $\mathrm{C}(2)-\mathrm{C}(3)-\mathrm{H}(15 \mathrm{~B})$ & 109.5 \\
\hline$H(15 A)-C(3)-H(15 B)$ & 109.5 \\
\hline $\mathrm{C}(2)-\mathrm{C}(3)-\mathrm{H}(15 \mathrm{C})$ & 109.5 \\
\hline$H(15 A)-C(3)-H(15 C)$ & 109.5 \\
\hline $\mathrm{H}(15 \mathrm{~B})-\mathrm{C}(3)-\mathrm{H}(15 \mathrm{C})$ & 109.5 \\
\hline $\mathrm{O}(3)-\mathrm{C}(4)-\mathrm{C}(7)$ & $114.59(18)$ \\
\hline $\mathrm{O}(3)-\mathrm{C}(4)-\mathrm{C}(6)$ & $105.25(18)$ \\
\hline$C(7)-C(4)-C(6)$ & 109.64(19) \\
\hline $\mathrm{O}(3)-\mathrm{C}(4)-\mathrm{C}(5)$ & $108.76(18)$ \\
\hline$C(7)-C(4)-C(5)$ & $108.70(19)$ \\
\hline$C(6)-C(4)-C(5)$ & $109.82(19)$ \\
\hline$F(1)-C(5)-F(2)$ & 106.92(19) \\
\hline$F(1)-C(5)-F(3)$ & 107.08(19) \\
\hline$F(2)-C(5)-F(3)$ & $106.3(2)$ \\
\hline$F(1)-C(5)-C(4)$ & $113.4(2)$ \\
\hline$F(2)-C(5)-C(4)$ & $110.54(19)$ \\
\hline$F(3)-C(5)-C(4)$ & 112.22(19) \\
\hline$F(6)-C(6)-F(5)$ & 106.92(19) \\
\hline$F(6)-C(6)-F(4)$ & $107.26(19)$ \\
\hline$F(5)-C(6)-F(4)$ & $106.6(2)$ \\
\hline$F(6)-C(6)-C(4)$ & $113.1(2)$ \\
\hline$F(5)-C(6)-C(4)$ & $109.93(19)$ \\
\hline$F(4)-C(6)-C(4)$ & $112.73(19)$ \\
\hline $\mathrm{C}(4)-\mathrm{C}(7)-\mathrm{H}(5 \mathrm{~A})$ & 109.5 \\
\hline $\mathrm{C}(4)-\mathrm{C}(7)-\mathrm{H}(5 \mathrm{~B})$ & 109.5 \\
\hline $\mathrm{H}(5 \mathrm{~A})-\mathrm{C}(7)-\mathrm{H}(5 \mathrm{~B})$ & 109.5 \\
\hline $\mathrm{C}(4)-\mathrm{C}(7)-\mathrm{H}(5 \mathrm{C})$ & 109.5 \\
\hline $\mathrm{H}(5 \mathrm{~A})-\mathrm{C}(7)-\mathrm{H}(5 \mathrm{C})$ & 109.5 \\
\hline $\mathrm{H}(5 \mathrm{~B})-\mathrm{C}(7)-\mathrm{H}(5 \mathrm{C})$ & 109.5 \\
\hline $\mathrm{O}(2)-\mathrm{C}(8)-\mathrm{C}(11)$ & $110.83(18)$ \\
\hline $\mathrm{O}(2)-\mathrm{C}(8)-\mathrm{C}(10)$ & $112.57(18)$ \\
\hline$C(11)-C(8)-C(10)$ & 108.95(19) \\
\hline $\mathrm{O}(2)-\mathrm{C}(8)-\mathrm{C}(9)$ & $106.15(18)$ \\
\hline$C(11)-C(8)-C(9)$ & $108.26(19)$ \\
\hline
\end{tabular}




$\begin{array}{ll}\mathrm{C}(10)-\mathrm{C}(8)-\mathrm{C}(9) & 109.96(19) \\ \mathrm{F}(8)-\mathrm{C}(9)-\mathrm{F}(7) & 107.40(19) \\ \mathrm{F}(8)-\mathrm{C}(9)-\mathrm{F}(9) & 107.28(19) \\ \mathrm{F}(7)-\mathrm{C}(9)-\mathrm{F}(9) & 106.16(19) \\ \mathrm{F}(8)-\mathrm{C}(9)-\mathrm{C}(8) & 112.84(19) \\ \mathrm{F}(7)-\mathrm{C}(9)-\mathrm{C}(8) & 110.25(19) \\ \mathrm{F}(9)-\mathrm{C}(9)-\mathrm{C}(8) & 112.54(19) \\ \mathrm{F}(10)-\mathrm{C}(10)-\mathrm{F}(12) & 107.27(19) \\ \mathrm{F}(10)-\mathrm{C}(10)-\mathrm{F}(11) & 106.92(18) \\ \mathrm{F}(12)-\mathrm{C}(10)-\mathrm{F}(11) & 105.90(18) \\ \mathrm{F}(10)-\mathrm{C}(10)-\mathrm{C}(8) & 113.46(19) \\ \mathrm{F}(12)-\mathrm{C}(10)-\mathrm{C}(8) & 110.70(18) \\ \mathrm{F}(11)-\mathrm{C}(10)-\mathrm{C}(8) & 112.17(19) \\ \mathrm{C}(8)-\mathrm{C}(11)-\mathrm{H}(9 \mathrm{~A}) & 109.5 \\ \mathrm{C}(8)-\mathrm{C}(11)-\mathrm{H}(9 \mathrm{~B}) & 109.5 \\ \mathrm{H}(9 \mathrm{~A})-\mathrm{C}(11)-\mathrm{H}(9 \mathrm{~B}) & 109.5 \\ \mathrm{C}(8)-\mathrm{C}(11)-\mathrm{H}(9 \mathrm{C}) & 109.5 \\ \mathrm{H}(9 \mathrm{~A})-\mathrm{C}(11)-\mathrm{H}(9 \mathrm{C}) & 109.5 \\ \mathrm{H}(9 \mathrm{~B})-\mathrm{C}(11)-\mathrm{H}(9 \mathrm{C}) & 109.5 \\ \mathrm{O}(1)-\mathrm{C}(12)-\mathrm{C}(15) & 114.22(18) \\ \mathrm{O}(1)-\mathrm{C}(12)-\mathrm{C}(13) & 109.62(17) \\ \mathrm{C}(15)-\mathrm{C}(12)-\mathrm{C}(13) & 109.23(18) \\ \mathrm{O}(1)-\mathrm{C}(12)-\mathrm{C}(14) & 104.74(17) \\ \mathrm{C}(15)-\mathrm{C}(12)-\mathrm{C}(14) & 109.02(18) \\ \mathrm{C}(13)-\mathrm{C}(12)-\mathrm{C}(14) & 109.88(18) \\ \mathrm{F}(17)-\mathrm{C}(13)-\mathrm{F}(18) & 106.59(18) \\ \mathrm{F}(17)-\mathrm{C}(13)-\mathrm{F}(16) & 106.71(18) \\ \mathrm{F}(18)-\mathrm{C}(13)-\mathrm{F}(16) & 106.72(18) \\ \mathrm{F}(17)-\mathrm{C}(13)-\mathrm{C}(12) & 112.95(18) \\ \mathrm{F}(18)-\mathrm{C}(13)-\mathrm{C}(12) & 110.51(18) \\ \mathrm{F}(16)-\mathrm{C}(13)-\mathrm{C}(12) & 112.95(18) \\ \mathrm{F}(13)-\mathrm{C}(14)-\mathrm{F}(14) & 106.85(19) \\ \mathrm{F}(13)-\mathrm{C}(14)-\mathrm{F}(15) & 106.92(19) \\ \mathrm{F}(14)-\mathrm{C}(14)-\mathrm{F}(15) & 106.81(19) \\ \mathrm{F}(13)-\mathrm{C}(14)-\mathrm{C}(12) & 110.06(19) \\ \mathrm{F}(14)-\mathrm{C}(14)-\mathrm{C}(12) & 113.00(18) \\ \mathrm{F}(15)-\mathrm{C}(14)-\mathrm{C}(12) & 112.84(19) \\ \mathrm{C}(12)-\mathrm{C}(15)-\mathrm{H}(13 \mathrm{~A}) & 109.5 \\ \mathrm{C}(12)-\mathrm{C}(15)-\mathrm{H}(13 \mathrm{~B}) & 109.5 \\ \mathrm{H}(13 \mathrm{~A})-\mathrm{C}(15)-\mathrm{H}(13 \mathrm{~B}) & 109.5 \\ \mathrm{C}(12)-\mathrm{C}(15)-\mathrm{H}(13 \mathrm{C}) & 109.5 \\ \mathrm{H}(13 \mathrm{~A})-\mathrm{C}(15)-\mathrm{H}(13 \mathrm{C}) & 109.5 \\ \mathrm{H}(13 \mathrm{~B})-\mathrm{C}(15)-\mathrm{H}(13 \mathrm{C}) & 109.5 \\ \mathrm{O}(4)-\mathrm{C}(16)-\mathrm{H}(16 \mathrm{~A}) & 109.5 \\ \mathrm{O}(4)-\mathrm{C}(16)-\mathrm{H}(16 \mathrm{~B}) & 109.5 \\ \mathrm{H}(16 \mathrm{~A})-\mathrm{C}(16)-\mathrm{H}(16 \mathrm{~B}) & 109.5 \\ \mathrm{O}(4)-\mathrm{C}(16)-\mathrm{H}(16 \mathrm{C}) & 109.5 \\ \mathrm{H}(16 \mathrm{~A})-\mathrm{C}(16)-\mathrm{H}(16 \mathrm{C}) & 109.5 \\ \mathrm{H}(16 \mathrm{~B})-\mathrm{C}(16)-\mathrm{H}(16 \mathrm{C}) & 109.5 \\ \mathrm{O}(4)-\mathrm{C}(17)-\mathrm{C}(18) & 108.47(18) \\ \mathrm{O}(4)-\mathrm{C}(17)-\mathrm{H}(17 \mathrm{~A}) & 110.0 \\ \mathrm{C}(18)-\mathrm{C}(17)-\mathrm{H}(17 \mathrm{~A}) & 110.0 \\ \mathrm{O}(4)-\mathrm{C}(17)-\mathrm{H}(17 \mathrm{~B}) & 110.0 \\ \mathrm{C}(18)-\mathrm{C}(17)-\mathrm{H}(17 \mathrm{~B}) & 110.0 \\ \mathrm{H}(17 \mathrm{~A})-\mathrm{C}(17)-\mathrm{H}(17 \mathrm{~B}) & 108.4 \\ \mathrm{O}(5)-\mathrm{C}(18)-\mathrm{C}(17) & 107.67(18) \\ & \end{array}$




$\begin{array}{lc}\text { O(5)-C(18)-H(18A) } & 110.2 \\ \mathrm{C}(17)-\mathrm{C}(18)-\mathrm{H}(18 \mathrm{~A}) & 110.2 \\ \mathrm{O}(5)-\mathrm{C}(18)-\mathrm{H}(18 \mathrm{~B}) & 110.2 \\ \mathrm{C}(17)-\mathrm{C}(18)-\mathrm{H}(18 \mathrm{~B}) & 110.2 \\ \mathrm{H}(18 \mathrm{~A})-\mathrm{C}(18)-\mathrm{H}(18 \mathrm{~B}) & 108.5 \\ \mathrm{O}(5)-\mathrm{C}(19)-\mathrm{H}(19 \mathrm{~A}) & 109.5 \\ \mathrm{O}(5)-\mathrm{C}(19)-\mathrm{H}(19 \mathrm{~B}) & 109.5 \\ \mathrm{H}(19 \mathrm{~A})-\mathrm{C}(19)-\mathrm{H}(19 \mathrm{~B}) & 109.5 \\ \mathrm{O}(5)-\mathrm{C}(19)-\mathrm{H}(19 \mathrm{C}) & 109.5 \\ \mathrm{H}(19 \mathrm{~A})-\mathrm{C}(19)-\mathrm{H}(19 \mathrm{C}) & 109.5 \\ \mathrm{H}(19 \mathrm{~B})-\mathrm{C}(19)-\mathrm{H}(19 \mathrm{C}) & 109.5 \\ \mathrm{C}(12)-\mathrm{O}(1)-\mathrm{Mo}(1) & 141.64(13) \\ \mathrm{C}(8)-\mathrm{O}(2)-\mathrm{Mo}(1) & 148.94(14) \\ \mathrm{C}(4)-\mathrm{O}(3)-\mathrm{Mo}(1) & 142.88(14) \\ \mathrm{C}(16)-\mathrm{O}(4)-\mathrm{C}(17) & 111.96(16) \\ \mathrm{C}(16)-\mathrm{O}(4)-\mathrm{Mo}(1) & 129.02(13) \\ \mathrm{C}(17)-\mathrm{O}(4)-\mathrm{Mo}(1) & 114.49(12) \\ \mathrm{C}(18)-\mathrm{O}(5)-\mathrm{C}(19) & 111.49(16) \\ \mathrm{C}(18)-\mathrm{O}(5)-\mathrm{Mo}(1) & 108.20(12) \\ \mathrm{C}(19)-\mathrm{O}(5)-\mathrm{Mo}(1) & 118.12(12) \\ \mathrm{C}(1)-\mathrm{Mo}(1)-\mathrm{O}(2) & 102.25(9) \\ \mathrm{C}(1)-\mathrm{Mo}(1)-\mathrm{O}(1) & 101.24(9) \\ \mathrm{O}(2)-\mathrm{Mo}(1)-\mathrm{O}(1) & 94.60(6) \\ \mathrm{C}(1)-\mathrm{Mo}(1)-\mathrm{O}(3) & 102.76(9) \\ \text { O(2)-Mo(1)-O(3) } & 94.27(6) \\ \text { O(1)-Mo(1)-O(3) } & 151.98(6) \\ \mathrm{C}(1)-\mathrm{Mo}(1)-\mathrm{O}(4) & 99.52(8) \\ \text { O(2)-Mo(1)-O(4) } & 158.23(6) \\ \text { O(1)-Mo(1)-O(4) } & 81.15(6) \\ \text { O(3)-Mo(1)-O(4) } & 80.80(6) \\ \mathrm{C}(1)-\mathrm{Mo}(1)-\mathrm{O}(5) & 171.68(8) \\ \text { O(2)-Mo(1)-O(5) } & 86.02(6) \\ \text { O(1)-Mo(1)-O(5) } & 76.96(5) \\ \text { O(3)-Mo(1)-O(5) } & 77.20(6) \\ \text { O(4)-Mo(1)-O(5) } & 72.21(5) \\ & \\ & \\ & \end{array}$

Symmetry transformations used to generate equivalent atoms: 
Table S5. Anisotropic displacement parameters $\left(\AA^{2} \times 10^{3}\right)$ for 2 . The anisotropic displacement factor exponent takes the form: $-2 \pi^{2}\left[h^{2} a^{2} U^{11}+\ldots+2 h k a^{*} b^{*} U^{12}\right]$

\begin{tabular}{|c|c|c|c|c|c|c|}
\hline & $U^{11}$ & $u^{22}$ & $u^{33}$ & $u^{23}$ & $U^{13}$ & $u^{12}$ \\
\hline$\overline{C(1)}$ & $21(1)$ & $14(1)$ & $25(1)$ & $-3(1)$ & $0(1)$ & $-1(1)$ \\
\hline$C(2)$ & $32(1)$ & $34(2)$ & 19(1) & $3(1)$ & $-3(1)$ & $-1(1)$ \\
\hline$C(3)$ & $95(3)$ & $80(3)$ & $28(2)$ & $11(2)$ & $4(2)$ & $62(2)$ \\
\hline$C(4)$ & 14(1) & 19(1) & $24(1)$ & $-4(1)$ & $0(1)$ & $-2(1)$ \\
\hline$C(5)$ & $18(1)$ & $27(1)$ & $30(1)$ & $-7(1)$ & $-2(1)$ & $-2(1)$ \\
\hline$C(6)$ & $20(1)$ & $25(1)$ & $31(1)$ & $-5(1)$ & $2(1)$ & $-8(1)$ \\
\hline$C(7)$ & $23(1)$ & $27(1)$ & $26(1)$ & $-7(1)$ & $-4(1)$ & $-1(1)$ \\
\hline$C(8)$ & 19(1) & $13(1)$ & $24(1)$ & $-4(1)$ & 2(1) & 1(1) \\
\hline C(9) & $21(1)$ & $16(1)$ & $33(1)$ & $-5(1)$ & $2(1)$ & $0(1)$ \\
\hline$C(10)$ & $25(1)$ & $18(1)$ & $25(1)$ & $-6(1)$ & $5(1)$ & $1(1)$ \\
\hline$C(11)$ & $22(1)$ & 15(1) & $31(1)$ & $-1(1)$ & 2(1) & $-2(1)$ \\
\hline$C(12)$ & $17(1)$ & 12(1) & 19(1) & $1(1)$ & $3(1)$ & $-3(1)$ \\
\hline$C(13)$ & $21(1)$ & $15(1)$ & $22(1)$ & $1(1)$ & 1(1) & $-1(1)$ \\
\hline$C(14)$ & 18(1) & $20(1)$ & $26(1)$ & $3(1)$ & 1(1) & $-3(1)$ \\
\hline$C(15)$ & $27(1)$ & 19(1) & $25(1)$ & $-2(1)$ & $8(1)$ & $-2(1)$ \\
\hline$C(16)$ & $25(1)$ & $15(1)$ & $29(1)$ & $1(1)$ & $-3(1)$ & $6(1)$ \\
\hline$C(17)$ & $25(1)$ & $19(1)$ & $19(1)$ & $-5(1)$ & $2(1)$ & $2(1)$ \\
\hline$C(18)$ & $22(1)$ & $22(1)$ & $18(1)$ & $-2(1)$ & $4(1)$ & $2(1)$ \\
\hline C(19) & $26(1)$ & 19(1) & $20(1)$ & $7(1)$ & $0(1)$ & 1(1) \\
\hline$F(1)$ & $28(1)$ & $31(1)$ & $33(1)$ & $-12(1)$ & $4(1)$ & $3(1)$ \\
\hline$F(2)$ & $31(1)$ & $26(1)$ & $36(1)$ & $1(1)^{\prime}$ & $-7(1)$ & $7(1)$ \\
\hline$F(3)$ & 16(1) & $40(1)$ & $60(1)$ & $-16(1)$ & $-7(1)$ & 1(1) \\
\hline$F(4)$ & $36(1)$ & $32(1)$ & $27(1)$ & $-2(1)$ & $7(1)$ & $-9(1)$ \\
\hline$F(5)$ & $33(1)$ & $20(1)$ & $46(1)$ & $3(1)$ & $8(1)$ & $-2(1)$ \\
\hline$F(6)$ & $27(1)$ & $37(1)$ & $49(1)$ & $-4(1)$ & 1(1) & $-18(1)$ \\
\hline$F(7)$ & $32(1)$ & $31(1)$ & $31(1)$ & $-4(1)$ & $-7(1)$ & $8(1)$ \\
\hline$F(8)$ & $21(1)$ & $28(1)$ & $63(1)$ & $6(1)$ & $-1(1)$ & $-6(1)$ \\
\hline$F(9)$ & $30(1)$ & 24(1) & $42(1)$ & $-8(1)$ & $3(1)$ & $10(1)$ \\
\hline$F(10)$ & $34(1)$ & $23(1)$ & $28(1)$ & $0(1)$ & $9(1)$ & $-5(1)$ \\
\hline$F(11)$ & $43(1)$ & $26(1)$ & $29(1)$ & $-11(1)$ & $9(1)$ & $6(1)$ \\
\hline$F(12)$ & $30(1)$ & $30(1)$ & $25(1)$ & $-4(1)$ & $-4(1)$ & $-1(1)$ \\
\hline$F(13)$ & $30(1)$ & $30(1)$ & $33(1)$ & $6(1)$ & $-3(1)$ & 12(1) \\
\hline$F(14)$ & $32(1)$ & $31(1)$ & $24(1)$ & $-7(1)$ & $-8(1)$ & 1(1) \\
\hline$F(15)$ & $25(1)$ & $52(1)$ & $45(1)$ & 18(1) & $-8(1)$ & $-19(1)$ \\
\hline$F(16)$ & $30(1)$ & $17(1)$ & $39(1)$ & $10(1)$ & $4(1)$ & $-5(1)$ \\
\hline$F(17)$ & $28(1)$ & 18(1) & $29(1)$ & $-4(1)$ & $2(1)$ & $5(1)$ \\
\hline$F(18)$ & $29(1)$ & $23(1)$ & $26(1)$ & $4(1)$ & $-7(1)$ & $2(1)$ \\
\hline$O(1)$ & 18(1) & 14(1) & 17(1) & $0(1)$ & 1(1) & $-3(1)$ \\
\hline$O(2)$ & $20(1)$ & $13(1)$ & $20(1)$ & $-4(1)$ & 2(1) & 1(1) \\
\hline$O(3)$ & $16(1)$ & $16(1)$ & $20(1)$ & $-1(1)$ & $-1(1)$ & $-4(1)$ \\
\hline $\mathrm{O}(4)$ & $22(1)$ & $12(1)$ & $20(1)$ & $-1(1)$ & $-1(1)$ & $4(1)$ \\
\hline O(5) & $17(1)$ & $17(1)$ & $16(1)$ & $1(1)$ & $2(1)$ & $0(1)$ \\
\hline $\mathrm{Mo}(1)$ & 14(1) & $10(1)$ & $14(1)$ & $-1(1)$ & 1(1) & $-1(1)$ \\
\hline
\end{tabular}


Table S6. Hydrogen coordinates $\left(\times 10^{4}\right)$ and isotropic displacement parameters $\left(\AA^{2} \times 10^{3}\right)$ for 2 .

\begin{tabular}{|c|c|c|c|c|}
\hline & $x$ & $y$ & $z$ & $U(e q)$ \\
\hline$\overline{H(14 A)}$ & 6684 & 2593 & 4000 & 34 \\
\hline$H(14 B)$ & 5949 & 1800 & 3835 & 34 \\
\hline$H(15 A)$ & 7702 & 1520 & 4597 & 102 \\
\hline $\mathrm{H}(15 \mathrm{~B})$ & 8396 & 1903 & 3722 & 102 \\
\hline$H(15 C)$ & 7659 & 1108 & 3558 & 102 \\
\hline $\mathrm{H}(5 \mathrm{~A})$ & 9591 & 3711 & 2657 & 38 \\
\hline$H(5 B)$ & 8460 & 3184 & 2851 & 38 \\
\hline $\mathrm{H}(5 \mathrm{C})$ & 8317 & 4080 & 2490 & 38 \\
\hline $\mathrm{H}(9 \mathrm{~A})$ & 5523 & 5306 & 2103 & 34 \\
\hline $\mathrm{H}(9 \mathrm{~B})$ & 5731 & 4947 & 1053 & 34 \\
\hline$H(9 C)$ & 6597 & 4721 & 1929 & 34 \\
\hline$H(13 A)$ & 4210 & 1771 & 2908 & 35 \\
\hline$H(13 B)$ & 2978 & 1368 & 2661 & 35 \\
\hline$H(13 C)$ & 3255 & 2238 & 2271 & 35 \\
\hline$H(16 A)$ & 8491 & 728 & 888 & 35 \\
\hline $\mathrm{H}(16 \mathrm{~B})$ & 7214 & 364 & 1006 & 35 \\
\hline $\mathrm{H}(16 \mathrm{C})$ & 7777 & 900 & 1845 & 35 \\
\hline$H(17 A)$ & 6134 & 1137 & -370 & 25 \\
\hline$H(17 B)$ & 7491 & 1034 & -605 & 25 \\
\hline $\mathrm{H}(18 \mathrm{~A})$ & 7679 & 2427 & -755 & 25 \\
\hline $\mathrm{H}(18 \mathrm{~B})$ & 6709 & 2103 & -1508 & 25 \\
\hline$H(19 A)$ & 5410 & 3753 & -465 & 33 \\
\hline$H(19 B)$ & 5877 & 3415 & -1464 & 33 \\
\hline$H(19 C)$ & 6782 & 3698 & -641 & 33 \\
\hline
\end{tabular}




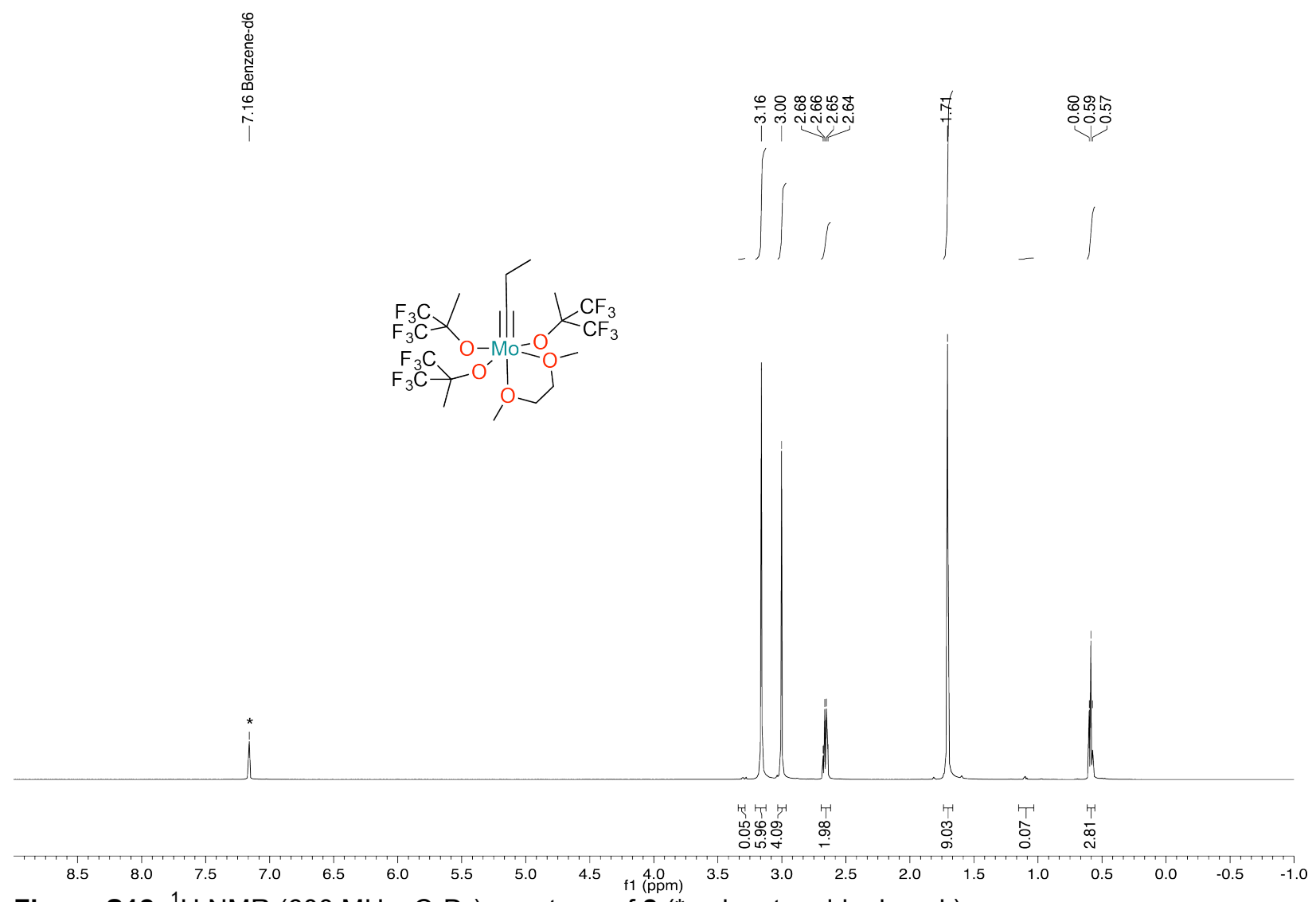

Figure S12. ${ }^{1} \mathrm{H}$ NMR (600 MHz, $\left.\mathrm{C}_{6} \mathrm{D}_{6}\right)$ spectrum of 2 ( ${ }^{*}$ solvent residual peak). 


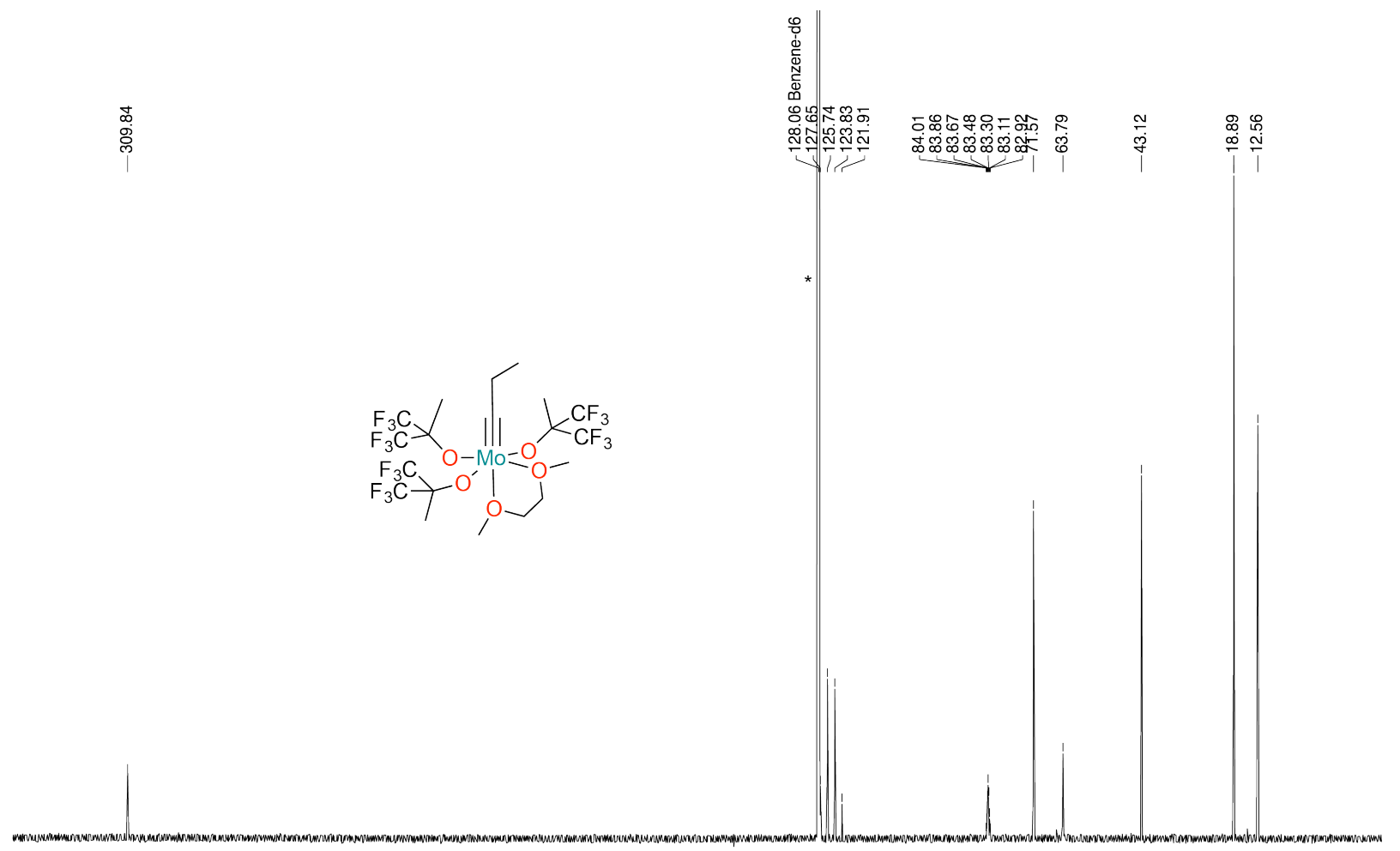

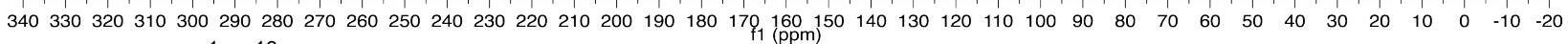
Figure S13. $\left\{{ }^{1} \mathrm{H}\right\}^{13} \mathrm{C}$ NMR (151 MHz, $\mathrm{C}_{6} \mathrm{D}_{6}$ ) spectrum of 2 ( ${ }^{*}$ solvent residual peak). 


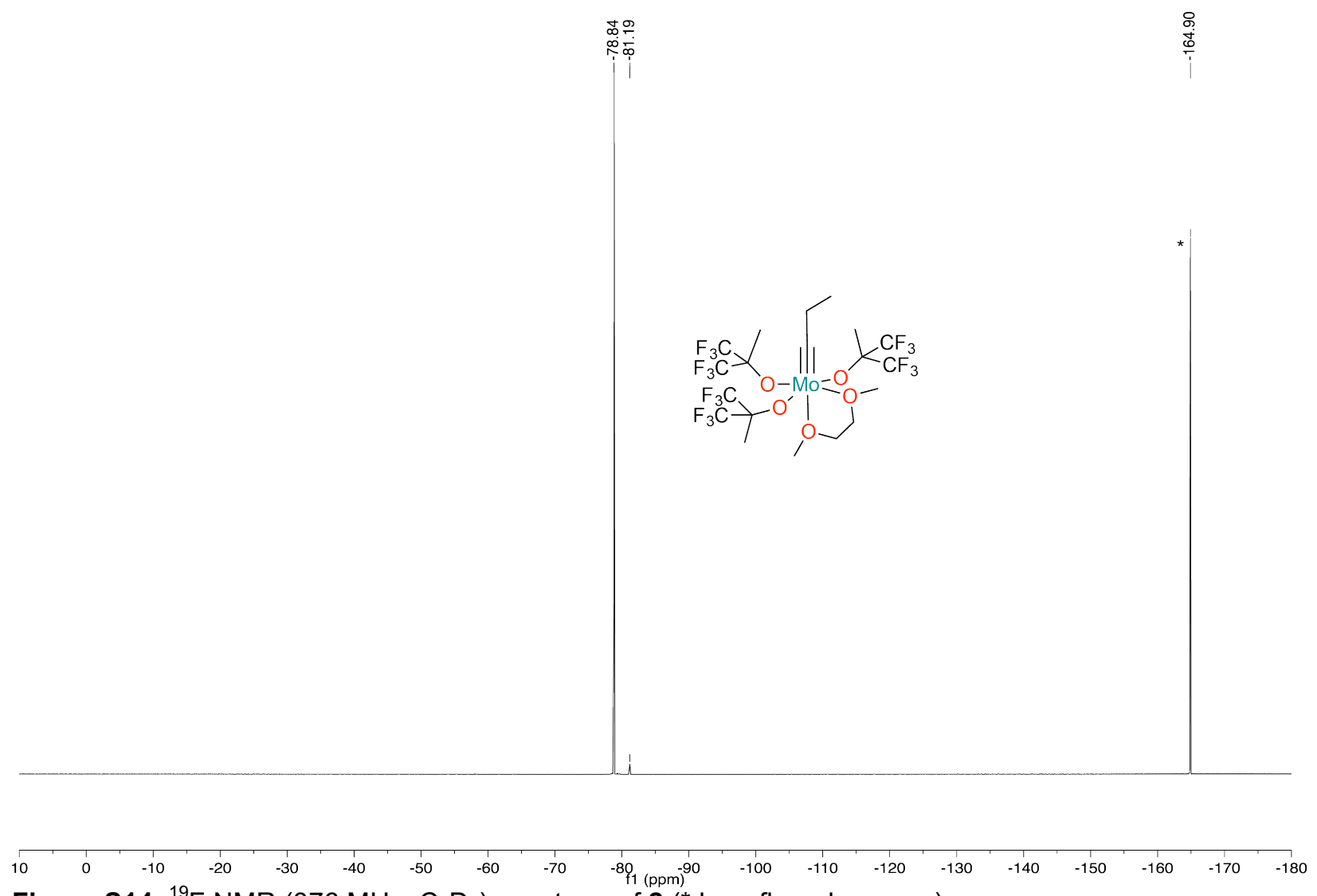

Figure S14. ${ }^{19} \mathrm{~F}$ NMR (376 MHz, $\mathrm{C}_{6} \mathrm{D}_{6}$ ) spectrum of 2 ( ${ }^{*}$ hexafluorobenzene). 


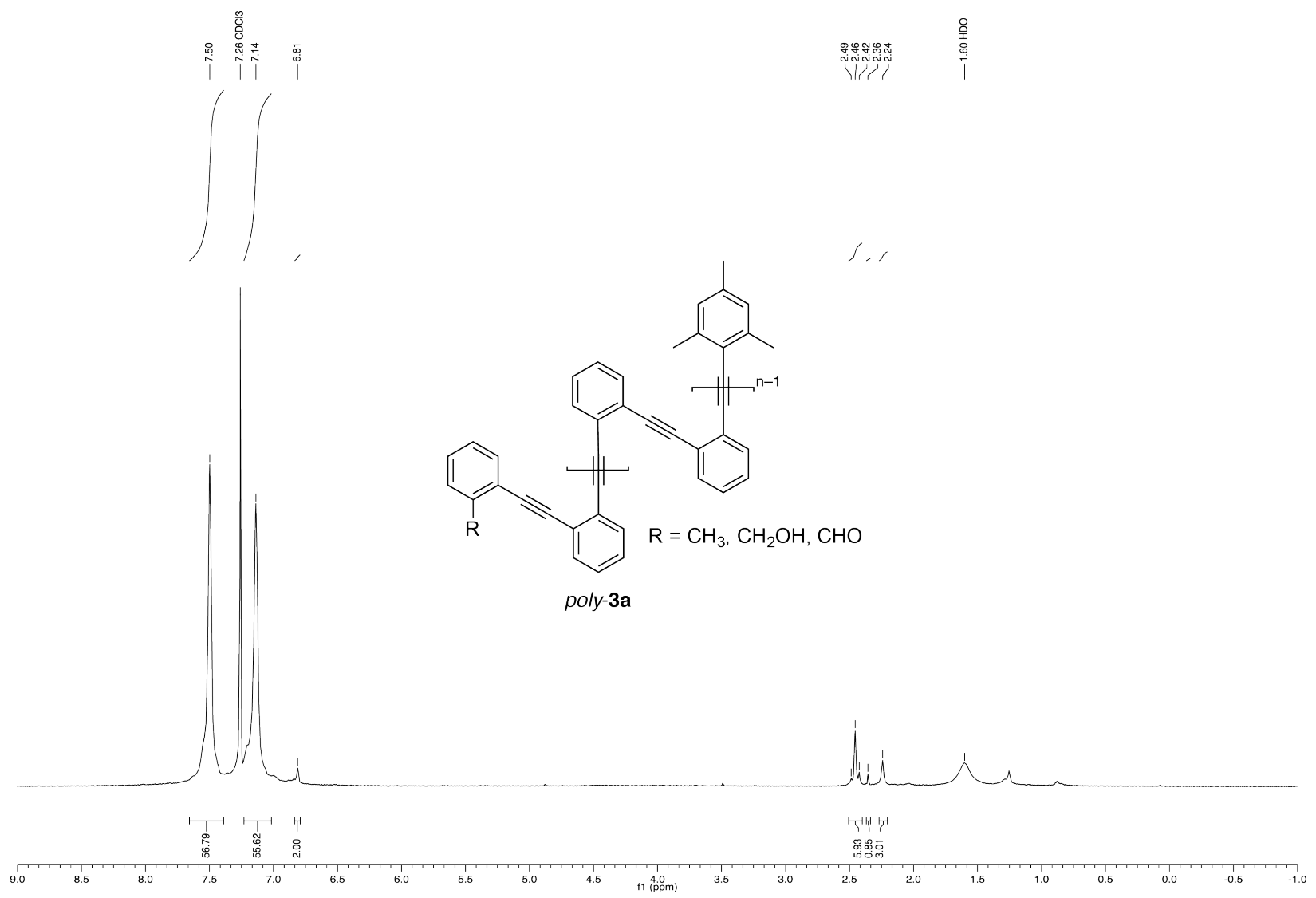

Figure S15. ${ }^{1} \mathrm{H}$ NMR $\left(600 \mathrm{MHz}, \mathrm{CDCl}_{3}\right)$ spectrum of linear poly-3a.

S31 

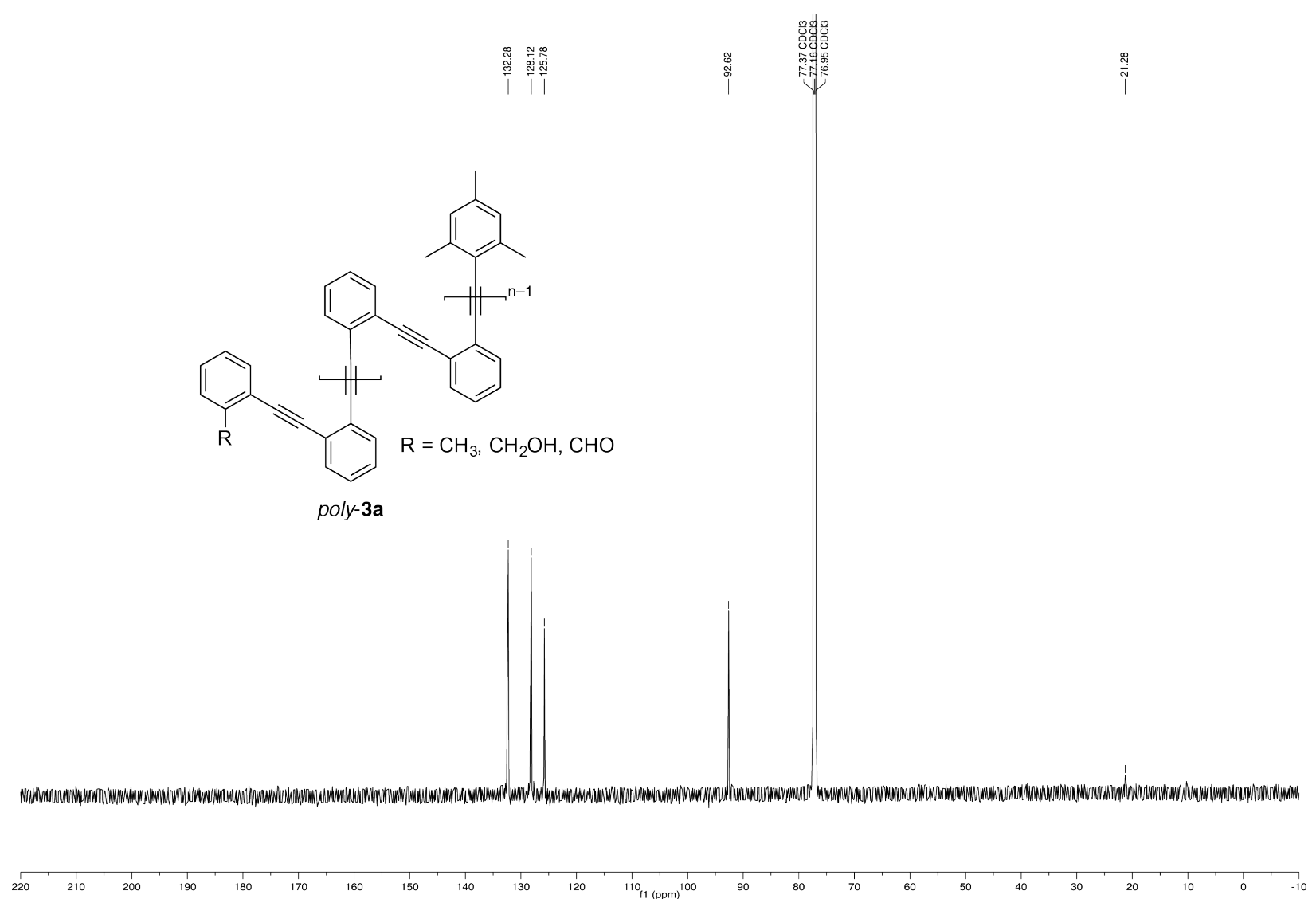

Figure S16. $\left\{{ }^{1} \mathrm{H}\right\}^{13} \mathrm{C}$ NMR $\left(126 \mathrm{MHz}, \mathrm{CDCl}_{3}\right)$ spectrum of linear poly-3a. 


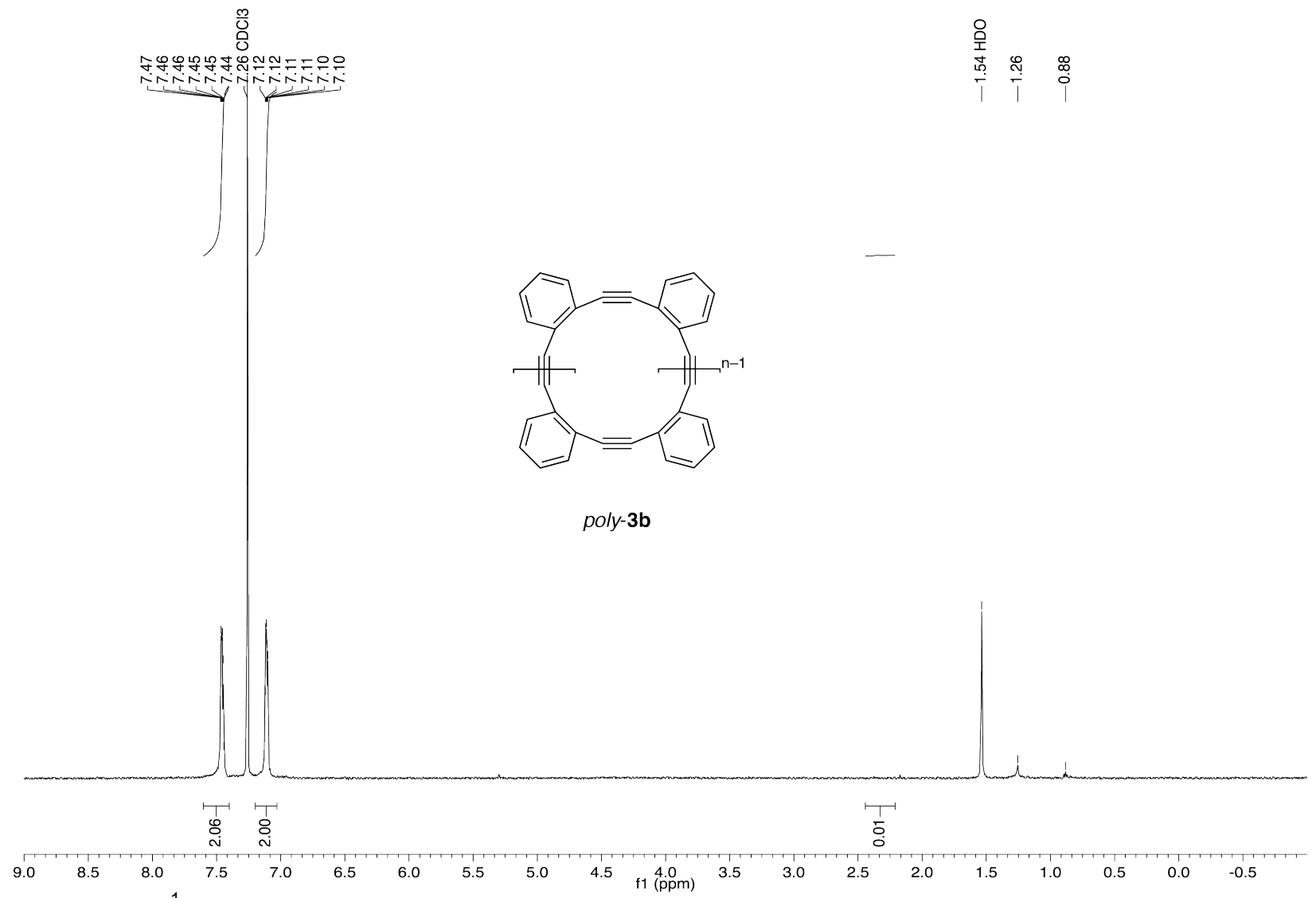

Figure S17. ${ }^{1} \mathrm{H}$ NMR $\left(600 \mathrm{MHz}, \mathrm{CDCl}_{3}\right)$ spectrum of cyclic poly-3b. 


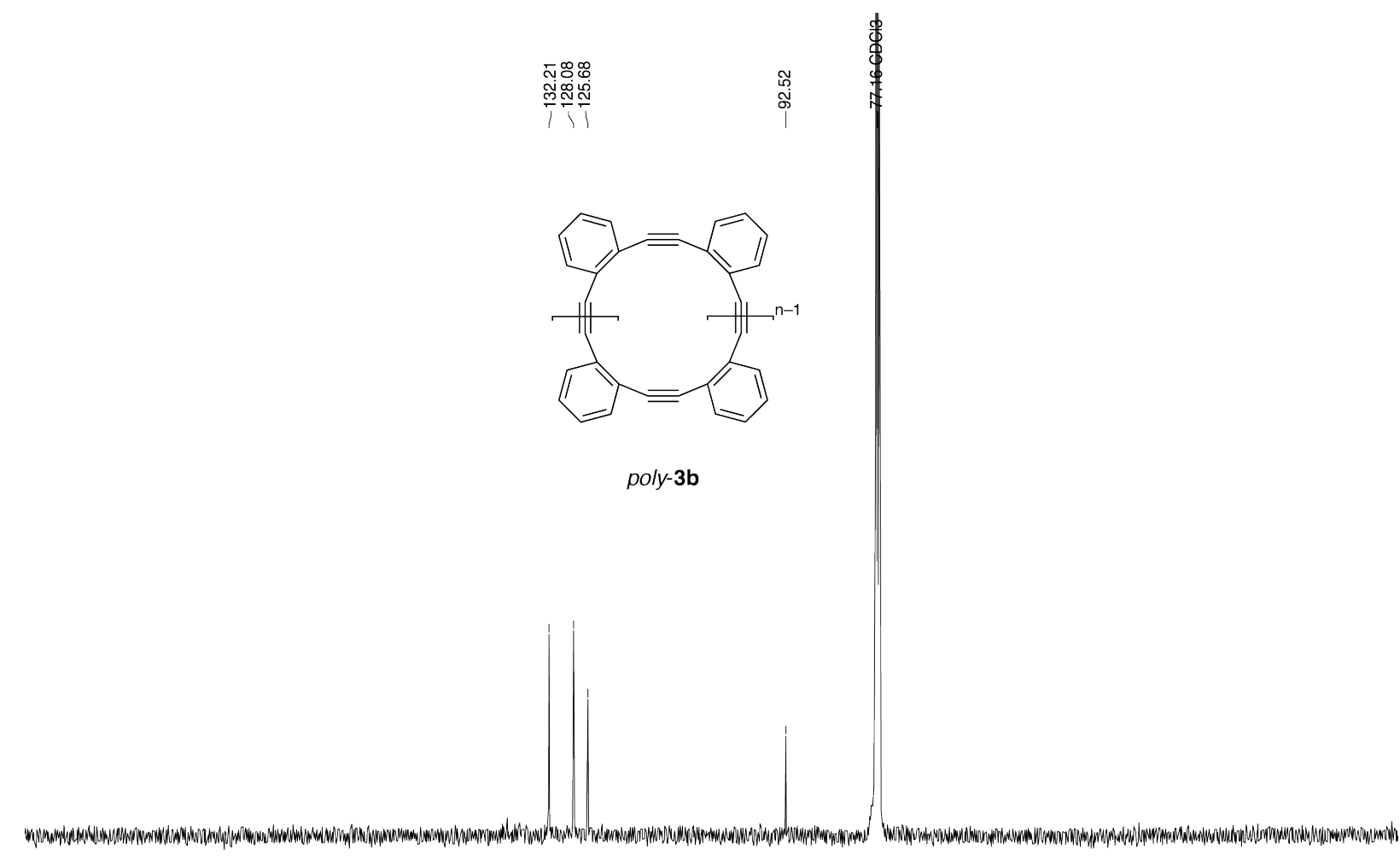

$\begin{array}{llllllllllllllllllllll}220 & 210 & 200 & 190 & 180 & 170 & 160 & 150 & 140 & 130 & 120 & \begin{array}{c}110 \\ \mathrm{f1}(\mathrm{ppm})\end{array} & 90 & 80 & 70 & 60 & 50 & 40 & 30 & 20 & 10 & 0\end{array}$ Figure S18. $\left\{{ }^{1} \mathrm{H}\right\}^{13} \mathrm{C}$ NMR $\left(126 \mathrm{MHz}, \mathrm{CDCl}_{3}\right)$ spectrum of cyclic poly-3b. 


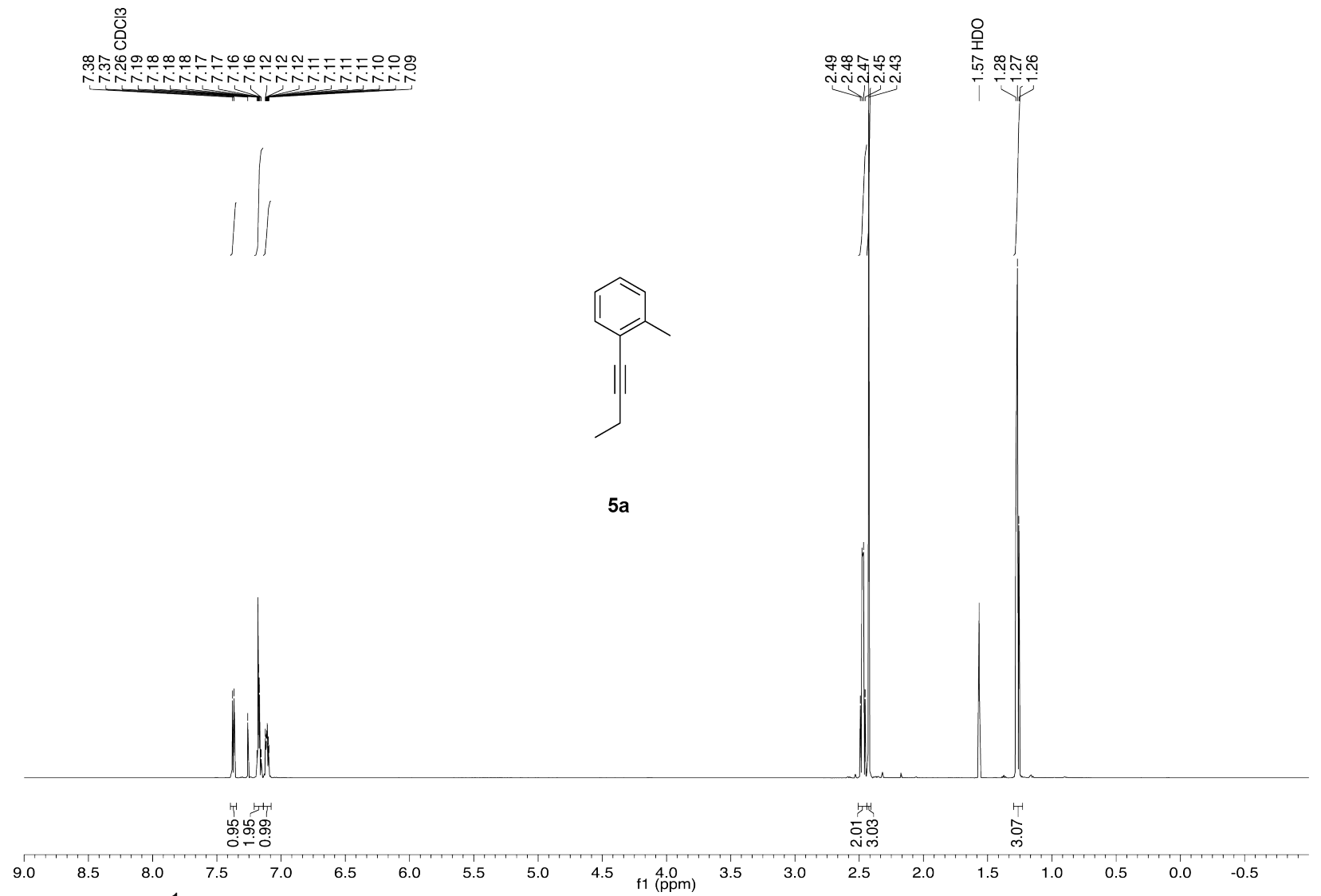

Figure S19. ${ }^{1} \mathrm{H}$ NMR $\left(600 \mathrm{MHz}, \mathrm{CDCl}_{3}\right)$ spectrum of $\mathbf{5 a}$. 

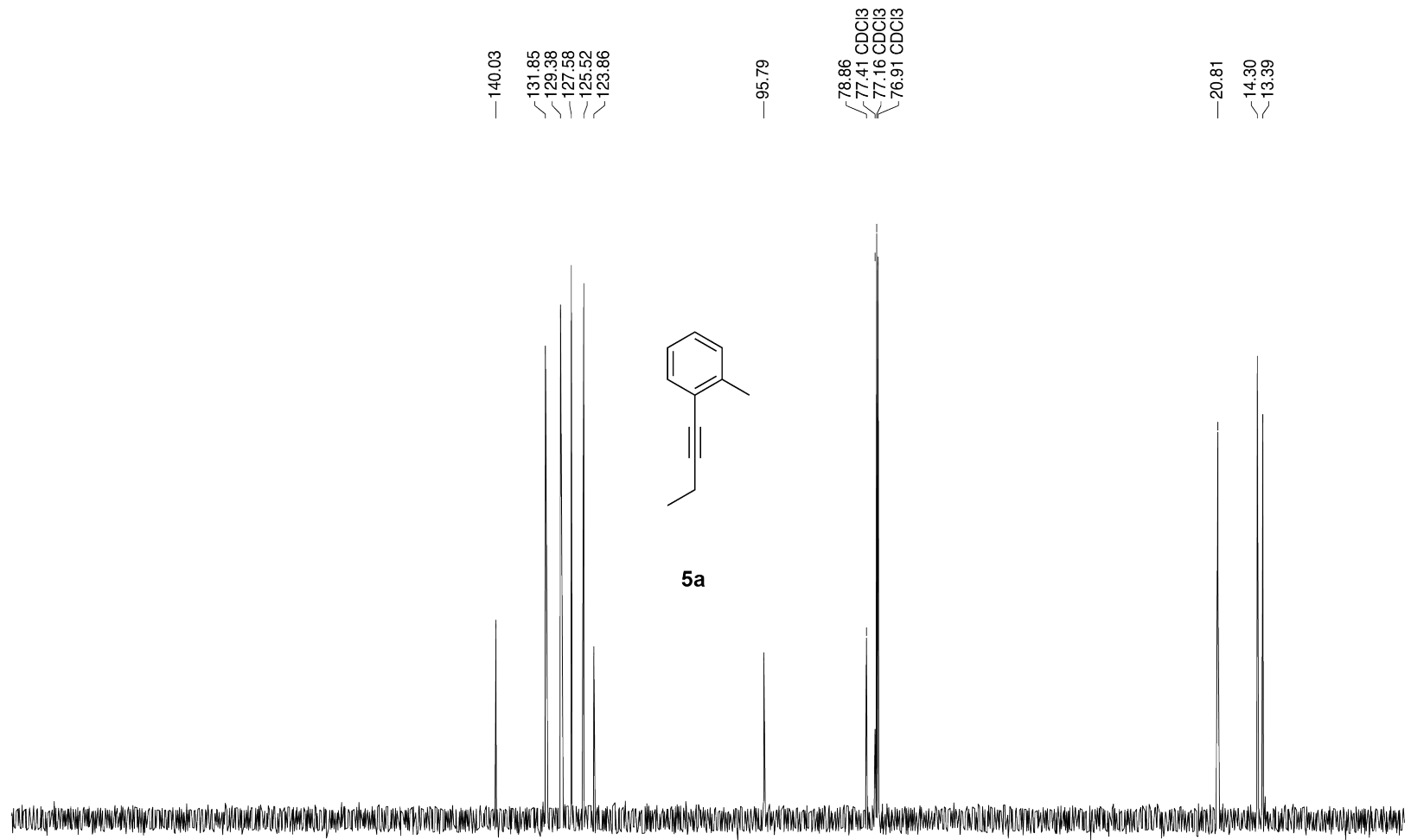

$\begin{array}{llllllllllllllllllllllll}210 & 200 & 190 & 180 & 170 & 160 & 150 & 140 & 130 & 120 & 110 & 100 & 90 & 80 & 70 & 60 & 50 & 40 & 30 & 20 & 10 & 0 & -10\end{array}$

Figure S20. $\left\{{ }^{1} \mathrm{H}\right\}^{13} \mathrm{C}$ NMR $\left(126 \mathrm{MHz}, \mathrm{CDCl}_{3}\right)$ spectrum of $\mathbf{5 a}$. 


\section{References}

(1) Solooki, D.; Ferrara, J. D.; Malaba, D.; Bradshaw, J. D.; Tessier, C. A.; Youngs, W. J.; John, J. A.; Tour, J. M. In Inorganic Syntheses; Cowley, A. H., Ed.; John Wiley \& Sons, Inc., 1996; pp 122-128.

(2) Solooki, D.; Bradshaw, J. D.; Tessier, C. A.; Youngs, W. J.; See, R. F.; Churchill, M.; Ferrara, J. D. J. Organomet. Chem. 1994, 470 (1), 231-236.

(3) Baldwin, K. P.; Bradshaw, J. D.; Tessier, C. A.; Youngs, W. J. Synlett 1993, 1993 (11), 853-855.

(4) Akoka, S.; Barantin, L.; Trierweiler, M. Anal. Chem. 1999, 71 (13), 2554-2557.

(5) Lakowicz, J. R. Principles of Fluorescence Spectroscopy (2nd) Second Edition, First Printing edition.; Kluwer Acacemic Publishers, 1999.

(6) Haberlag, B.; Freytag, M.; Daniliuc, C. G.; Jones, P. G.; Tamm, M. Angew. Chem. Int. Ed. 2012, 51 (52), 13019-13022. 